\title{
Energy losses in the hydraulic rotational motor definitions and relations for evaluation of the efficiency of motor and hydrostatic drive
}

\author{
Zygmunt Paszota, Prof. \\ Gdansk University of Technology
}

\begin{abstract}
The evaluation methods of energy losses and efficiency of the hydraulic rotational motors for the hydrostatic drives, used so far in the scientific research and in the industrial practice, give wrong results because the parameters that the losses and efficiencies are a function of are themselves dependent on those losses.

The aim of the paper is to define the motor operating parameters, developed powers, energy losses and efficiencies and also to show the respective relations. Conclusions are drawn, based on the analyses of presented definitions and relations, on the motor energy investigations.
\end{abstract}

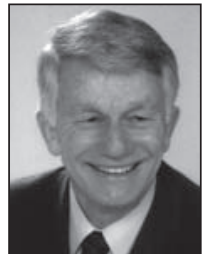

Keywords: hydrostatic drive; hydraulic motor; energy efficiency

\section{INTRODUCTION}

Evaluation of the energy behaviour of a hydraulic motor is an evaluation of its overall efficiency $\eta_{\mathrm{M}}=\mathrm{f}\left(\mathrm{n}_{\mathrm{M}}, \mathrm{M}_{\mathrm{M}}, v\right)$, i.e. evaluation of the overall efficiency $\eta_{M}$ as a function of motor shaft speed $n_{M}$ and load $M_{M}$ and of the working fluid viscosity $v$. This is also assessment of the value and proportions of the motor mechanical, volumetric and pressure losses deciding of the motor mechanical $\eta_{\mathrm{Mm}}$, volumetric $\eta_{\mathrm{Mv}}$ and pressure $\eta_{\mathrm{Mp}}$ efficiency, where the product $\eta_{\mathrm{M}}=\eta_{\mathrm{Mm}} \eta_{\mathrm{Mv}} \eta_{\mathrm{Mp}}$ determines the motor overall efficiency $\eta_{\mathrm{M}}$. The energy losses and the corresponding efficiencies $\eta_{\mathrm{Mm}}, \eta_{\mathrm{Mv}}$ and $\eta_{\mathrm{Mp}}$ should be determined as a function of parameters having a direct impact on the particular losses and efficiencies.

Designers and makers of rotational hydraulic motors and hydrostatic systems have not had so far a tool to determine their energy behaviour in the $\left(0 \leq \bar{\omega}_{\mathrm{M}}\left\langle\bar{\omega}_{\mathrm{M} \max }, 0 \leq \overline{\mathrm{M}}_{\mathrm{M}}\left\langle\overline{\mathrm{M}}_{\mathrm{M} \max }\right)\right.\right.$ field of change of the hydraulic motor shaft speed and load coefficients and in the $v_{\min } \leq v \leq v_{\max }$ field of change of the working fluid viscosity.

The rotational motor producers make erroneous routine evaluations of the following energy efficiencies and work parameters:

- the motor overall efficiency $\eta_{\mathrm{M}}$ as a function of the shaft speed $n_{M}$ and motor pressure decrease $\Delta \mathrm{p}_{\mathrm{M}}$ (e.g. $\left.[11 \div 14]\right)$

- the motor overall efficiency $\eta_{M}$ as a product of the volumetric efficiency $\eta_{\mathrm{Mv}}$ and the so called ,mechanical - hydraulic efficiency" $\eta_{\mathrm{Mmh}}$, determined all the three as a function of the same parameters (e.g. $[11,12])$

- motor shaft speed $n_{M}$ as a function of the motor capacity $Q_{M}$ and volumetric efficiency $\eta_{\mathrm{Mv}}$, determined in turn as a function of the motor pressure decrease $\Delta \mathrm{p}_{\mathrm{M}}$ (e.g. $\left.[11,13]\right)$
- motor shaft torque $M_{M}$ as a function of pressure decrease $\Delta \mathrm{p}_{\mathrm{M}}$ and the so called ",mechanical - hydraulic efficiency" $\eta_{\mathrm{Mmh}}$ of the motor (e.g. $\left.[11 \div 14]\right)$

- motor capacity $Q_{M}$ as a function of the shaft speed $n_{M}$ and volumetric efficiency $\eta_{\mathrm{Mv}}$, determined in turn as a function of the motor pressure decrease $\Delta \mathrm{p}_{\mathrm{M}}$ (e.g. $\left.[11 \div 13]\right)$

- motor shaft usefull power $\mathrm{P}_{\mathrm{Mu}}$ as a function of the motor capacity $\mathrm{Q}_{\mathrm{M}}$ and pressure decrease $\Delta \mathrm{p}_{\mathrm{M}}$ and as a function of the motor overall efficiency $\eta_{\mathrm{M}}$ determined in turn as a function of the motor shaft speed $\mathrm{n}_{\mathrm{M}}$ and pressure decrease $\Delta \mathrm{p}_{\mathrm{M}}($ e.g. $[11 \div 13])$.

The hydraulic motor researchers evaluate in a wrong way the losses arising in the motor:

- the motor torque $\mathrm{M}_{\mathrm{Mm}}$ of mechanical losses as a function of the motor pressure decrease $\Delta \mathrm{p}_{\mathrm{M}}$ and shaft speed $\mathrm{n}_{\mathrm{M}}$

- a sum of torque $\mathrm{M}_{\mathrm{Mm}}$ of mechanical losses and the so called „torque of pressure losses” (resulting from the pressure losses $\Delta \mathrm{p}_{\mathrm{M}}$ in the motor) - as a function of motor pressure decrease $\Delta \mathrm{p}_{\mathrm{M}}$ and the shaft speed $\mathrm{n}_{\mathrm{M}}$

- the intensity $\mathrm{Q}_{\mathrm{Mv}}$ of volumetric losses in the motor as a function of the motor pressure decrease $\Delta \mathrm{p}_{\mathrm{M}}$ (or as a function of the motor shaft torque $\mathrm{M}_{\mathrm{M}}$ ) and as a function of the motor shaft speed $n_{M}$.

The evaluation methods of the energy losses and efficiency of the rotational hydraulic motors, used so far in the scientific research and in the industrial practice give wrong results because the parameters that the losses and efficiencies are a function of are themselves dependent of those losses.

There are very few informations of the motor makers presenting properly the motor overall efficiency $\eta_{M}=f\left(n_{M}\right.$, 
$M_{M}$ ) as a function of the motor shaft speed $n_{M}$ and torque $M_{M}$ at a specified fluid viscosity $v$ and presenting the impact of viscosity $v$ on the overall efficiency $\eta_{M}$ (e.g. [10]).

It is a common deficiency that no information is given about the dependence of the motor mechanical, volumetric and pressure losses on the kinematic viscosity $v$ of the working fluid used in the hydrostatic drive system.

The fundamental reason of the erroneous evaluations are commonly accepted views on the research methodology and on the method of determining the energy losses in pumps and in hydraulic motors. That method is based, among others, on the traditional reading of the energy balance of a hydrostatic drive system from the Sankey diagram $[1 \div 9]$. The present unsatisfactory state is also effect of using simplified evaluations of the relations of particular losses to the motor or pump working parameters and to the working fluid viscosity.

Therefore, the aim of this paper is to define the work parameters, developed powers, losses and energy efficiency of a rotational hydraulic motor and also demonstrating their complex interdependence. The analysis of those definitions and relations will be a basis of conclusions regarding the investigations of motor energy characteristics.

\section{ROTATIONAL HYDRAULIC MOTOR - WORK PARAMETERS, POWERS, ENERGY LOSSES, ENERGY EFFICIENCY - DEFINITIONS AND RELATIONS}

- Motor shaft rotational (angular) speed $n_{M}\left(\omega_{M}\right)$ varies in the $\left(0 \leq \bar{\omega}_{M}\left\langle\bar{\omega}_{M \max }, 0 \leq \bar{M}_{M}\left\langle\bar{M}_{M \max }\right)\right.\right.$ field of the hydrostatic drive system operation. The instantaneous $n_{M}\left(\omega_{M}\right)$ value is required by the machine (device) driven by the motor. The instantaneous value of the $\mathrm{n}_{\mathrm{M}}\left(\omega_{\mathrm{M}}\right)$ speed is independent of the instantaneous value of the $\mathrm{M}_{\mathrm{M}}$ torque loading the motor shaft and also independent of the energy losses in the hydraulic motor and in the hydrostatic drive system.

- $\underline{M}_{M}$ torque loading the motor shaft varies in the $\left(0 \leq \frac{M}{\omega_{M}}\left\langle\bar{\omega}_{M \max }, 0 \leq \bar{M}_{M}\left\langle\bar{M}_{M \max }\right)\right.\right.$ field of the hydrostatic drive system operation. The instantaneous value of $\mathrm{M}_{\mathrm{M}}$ torque is required by the motor driven machine (device). The instantaneous value of $M_{M}$ torque is independent of the instantaneous value of the required motor shaft speed $n_{M}$ $\left(\omega_{\mathrm{M}}\right)$ and also of the energy losses in a hydraulic motor and in the hydrostatic drive system.

- Working fluid (hydraulic oil, oil-water emulsion) kinematic viscosity $v$ changes in the $v_{\min } \leq v \leq v_{\max }$ range. The instantaneous value $v$ of the viscosity of fluid flux reaching the hydraulic motor is independent of the motor and of the energy losses in the motor.

- Motor useful power $\mathrm{P}_{\mathrm{Mu}}$, required on the motor shaft by the driven machine (device), is a product of the required $\mathrm{M}_{\mathrm{M}}$ torque loading the motor shaft and the required shaft angular speed $\omega_{\mathrm{M}}$ :

$$
\mathrm{P}_{\mathrm{Mu}}=\mathrm{M}_{\mathrm{M}} \omega_{\mathrm{M}}=2 \Pi \mathrm{M}_{\mathrm{M}} \mathrm{n}_{\mathrm{M}}
$$

The motor useful power $\mathrm{P}_{\mathrm{Mu}}$ is independent of the energy losses in the hydraulic motor and the hydrostatic drive system.

- $\underline{M}_{\mathrm{Mm}}$ torque of mechanical losses in the motor, occurring in the „shaft - working chambers" assembly, is a function of the required $\mathrm{M}_{\mathrm{M}}$ torque loading the motor shaft and of the required shaft rotational speed $n_{M}$. The $n_{M}$ speed influences the inertia forces of ,shaft - working chambers" assembly elements and in effect the friction losses in the piston, satellite and vane motors. The $\mathrm{M}_{\mathrm{Mm}}$ torque of losses is to a some extent also a function of the working fluid viscosity $v$.
The impact of fluid viscosity on the mechanical losses in the ,shaft - working chambers" assembly occurs mainly in the piston motors with fluid in the motor casing:

$$
\mathrm{M}_{\mathrm{Mm}}=\mathrm{f}\left(\mathrm{M}_{\mathrm{M}}, \mathrm{n}_{\mathrm{M}}, v\right)
$$

Power $\Delta \mathrm{P}_{\mathrm{Mm}}$ of mechanical losses in the motor, occuring in the ,shaft - working chambers" assembly, is a product of the $\mathrm{M}_{\mathrm{Mm}}$ torque of mechanical losses and shaft angular speed $\omega_{\mathrm{M}}$ :

$$
\Delta \mathrm{P}_{\mathrm{Mm}}=\mathrm{M}_{\mathrm{Mm}} \omega_{\mathrm{M}}=2 \Pi \mathrm{M}_{\mathrm{Mm}} \mathrm{n}_{\mathrm{M}}
$$

- $\underline{\mathrm{M}}_{\mathrm{Mi}}$ indicated torque in the motor working chambers (at the point of conversion of the working fluid pressure energy into mechanical energy of the "shaft - working chambers" assembly), required by the motor from the driving working fluid, must be greater than the $\mathrm{M}_{\mathrm{M}}$ torque loading the motor shaft [required by the driven machine (device)] because of the necessity of balancing also the $\mathrm{M}_{\mathrm{Mm}}$ torque of mechanical losses in the "shaft - working chambers" assembly. The $\mathrm{M}_{\mathrm{Mi}}$ torque is equal to the sum of shaft torque $\mathrm{M}_{\mathrm{M}}$ and $\mathrm{M}_{\mathrm{Mm}}$ torque of mechanical losses. The indicated torque $\mathrm{M}_{\mathrm{Mi}}$ requires a value of the product of decrease $\Delta \mathrm{p}_{\mathrm{Mi}}$ of the indicated pressure in working chambers and the theoretical motor capacity $\mathrm{q}_{\mathrm{Mt}}$ per one shaft revolution (theoretical motor working volume $\mathrm{V}_{\mathrm{Mt}}$ ) in accordance with the expression:

$$
\frac{\Delta \mathrm{p}_{\mathrm{Mi}} \mathrm{q}_{\mathrm{Mt}}}{2 \Pi}=\mathrm{M}_{\mathrm{Mi}}=\mathrm{M}_{\mathrm{M}}+\mathrm{M}_{\mathrm{Mm}}
$$

The $\mathrm{M}_{\mathrm{Mi}}$ torque indicated in the motor working chambers is not a function of the decrease $\Delta \mathrm{p}_{\mathrm{Mi}}$ and of theoretical motor capacity $\mathrm{q}_{\mathrm{Mt}}$ per one shaft revolution.

For evaluation of the $\mathrm{M}_{\mathrm{Mi}}$ torque indicated in the motor working chambers a formula can be used relating the $\mathrm{M}_{\mathrm{M}}$ torque loading the motor shaft with the known motor mechanical efficiency $\eta_{\mathrm{Mm}}$ [formula (11)]:

$$
\frac{\Delta \mathrm{p}_{\mathrm{Mi}} \mathrm{q}_{\mathrm{Mt}}}{2 \Pi}=\mathrm{M}_{\mathrm{Mi}}=\frac{\mathrm{M}_{\mathrm{M}}}{\eta_{\mathrm{Mm}}}
$$

with: $\eta_{M m}=f\left(M_{M m}, M_{M}\right)=f\left(M_{M}, n_{M}, v\right)$

i.e. a formula where mechanical efficiency $\eta_{\mathrm{Mm}}$ is defined as a function of parameters influencing the $\mathrm{M}_{\mathrm{Mm}}$ torque of mechanical losses in the "shaft - working chambers" assembly and as a function of the $\mathrm{M}_{\mathrm{M}}$ torque loading the motor shaft.

- Pressure decrease $\Delta \mathrm{p}_{\mathrm{Mi}}$ indicated in the motor working chambers is a function of the required $\mathrm{M}_{\mathrm{Mi}}$ torque indicated in the chambers and theoretical capacity $\mathrm{q}_{\mathrm{Mt}}$ per one shaft revolution:

$$
\Delta \mathrm{p}_{\mathrm{Mi}}=\frac{2 \Pi \mathrm{M}_{\mathrm{Mi}}}{\mathrm{q}_{\mathrm{Mt}}}=\frac{2 \Pi\left(\mathrm{M}_{\mathrm{M}}+\mathrm{M}_{\mathrm{Mm}}\right)}{\mathrm{q}_{\mathrm{Mt}}}
$$

Therefore, the pressure decrease $\Delta \mathrm{p}_{\mathrm{Mi}}$ indicated in the motor working chambers (with determined theoretical capacity $\mathrm{q}_{\mathrm{Mt}}$ per one shaft revolution) is a function of the required $\mathrm{M}_{\mathrm{M}}$ torque loading the motor shaft and the $\mathrm{M}_{\mathrm{Mm}}$ torque of mechanical losses in the ,shaft - working chambers" assembly. The pressure decrease $\Delta \mathrm{p}_{\mathrm{Mi}}$ is indirectly a function of the shaft rotational speed $\mathrm{n}_{\mathrm{M}}$ and a function of the working fluid viscosity $v$, which have an impact (apart from $\mathrm{M}_{\mathrm{M}}$ ) on the $\mathrm{M}_{\mathrm{Mm}}$ torque of mechanical losses:

$$
\Delta \mathrm{p}_{\mathrm{Mi}}=\mathrm{f}\left(\mathrm{M}_{\mathrm{M}}, \mathrm{M}_{\mathrm{Mm}}\right)=\mathrm{f}\left(\mathrm{M}_{\mathrm{M}}, \mathrm{n}_{\mathrm{M}}, \mathrm{v}\right)
$$

For evaluation of the decrease $\Delta \mathrm{p}_{\mathrm{Mi}}$ of pressure indicated in the motor working chambers (with determined theoretical 
capacity $\mathrm{q}_{\mathrm{Mt}}$ per one shaft revolution) a formula can be used relating the $\mathrm{M}_{\mathrm{M}}$ torque loading the motor shaft with the known motor mechanical efficiency $\eta_{\mathrm{Mm}}$ [formula (11)]:

$$
\Delta \mathrm{p}_{\mathrm{Mi}}=\frac{2 \Pi \mathrm{M}_{\mathrm{M}}}{\mathrm{q}_{\mathrm{Mt}} \eta_{\mathrm{Mm}}}
$$

with: $\eta_{M m}=f\left(M_{M m}, M_{M}\right)=f\left(M_{M}, n_{M}, v\right)$

i.e. a formula where mechanical efficiency $\eta_{\mathrm{Mm}}$ is defined as a function of parameters influencing the $\mathrm{M}_{\mathrm{Mm}}$ torque of mechanical losses in the "shaft - working chambers" assembly and as a function of the $\mathrm{M}_{\mathrm{M}}$ torque loading the motor shaft.

- $\underline{\mathrm{P}}_{\mathrm{Mi}}$ indicated power in the motor working chambers is required by the motor from the driving working fluid at the point of conversion of the working fluid pressure energy into mechanical energy of the ,shaft - working chambers" assembly. The $\mathrm{P}_{\mathrm{Mi}}$ is equal to the product of the $\mathrm{M}_{\mathrm{Mi}}$ torque indicated in the chambers and the shaft angular speed $\omega_{\mathrm{M}}$. The power $\mathrm{P}_{\mathrm{i}}$ indicated in the working chamber is a sum of useful power $\mathrm{P}_{\mathrm{Mu}}$ [required on the motor shaft by the driven machine (device) ] and the power $\Delta \mathrm{P}_{\mathrm{Mm}}$ of mechanical losses in the ,shaft - working chambers" assembly:

$$
\begin{gathered}
\frac{\Delta \mathrm{p}_{\mathrm{Mi}} \mathrm{q}_{\mathrm{Mt}}}{2 \Pi} \omega_{\mathrm{M}}=\Delta \mathrm{p}_{\mathrm{Mi}} \mathrm{q}_{\mathrm{Mt}} \mathrm{n}_{\mathrm{M}}=\mathrm{P}_{\mathrm{Mi}}= \\
=\mathrm{M}_{\mathrm{Mi}} \omega_{\mathrm{M}}=\left(\mathrm{M}_{\mathrm{M}}+\mathrm{M}_{\mathrm{Mm}}\right) \omega_{\mathrm{M}}=\mathrm{P}_{\mathrm{Mu}}+\Delta \mathrm{P}_{\mathrm{Mm}}
\end{gathered}
$$

The $\mathrm{P}_{\mathrm{Mi}}$ power indicated in the motor working chambers is not a function of the decrease $\Delta \mathrm{p}_{\mathrm{Mi}}$ of pressure indicated in the chambers and of theoretical motor capacity $\mathrm{q}_{\mathrm{Mt}}$ per one shaft revolution.

For evaluation of the $\mathrm{P}_{\mathrm{Mi}}$ power indicated in the motor working chambers a formula can be used relating the motor shaft useful power $\mathrm{P}_{\mathrm{Mu}}$ with the known motor mechanical efficiency $\eta_{\mathrm{Mm}}$ [formula (11)]:

$$
\mathrm{P}_{\mathrm{Mi}}=\frac{\mathrm{P}_{\mathrm{Mu}}}{\eta_{\mathrm{Mm}}}
$$

with: $\eta_{M m}=f\left(M_{M m}, M_{M}\right)=f\left(M_{M}, n_{M}, v\right)$

i.e. a formula, where mechanical efficiency $\eta_{\mathrm{Mm}}$ is defined as a function of parameters influencing the $\mathrm{M}_{\mathrm{Mm}}$ torque of mechanical losses in the "shaft - working chambers" assembly and as a function of the $\mathrm{M}_{\mathrm{M}}$ torque loading the motor shaft.

- The motor mechanical efficiency $\eta_{M m}$ is a ratio of useful power $\mathrm{P}_{\mathrm{Mu}}$ on the shaft [required by the motor driven machine (device)] to the power $\mathrm{P}_{\mathrm{Mi}}$ indicated in the motor working chambers (required by the motor of the driving fluid at the point of conversion (change) of the working fluid pressure energy into the mechanical energy of the „shaft - working chambers" assembly). The $\eta_{\mathrm{Mm}}$ efficiency can be also determined by the ratio of motor shaft torque $\mathrm{M}_{\mathrm{M}}$ to the torque $\mathrm{M}_{\mathrm{Mi}}$ indicated in the working chambers:

$$
\begin{gathered}
\eta_{\mathrm{Mm}}=\frac{\mathrm{P}_{\mathrm{Mu}}}{\mathrm{P}_{\mathrm{Mi}}}=\frac{\mathrm{P}_{\mathrm{Mu}}}{\mathrm{P}_{\mathrm{Mu}}+\Delta \mathrm{P}_{\mathrm{Mm}}}= \\
=\frac{\mathrm{M}_{\mathrm{M}} \omega_{\mathrm{M}}}{\left(\mathrm{M}_{\mathrm{M}}+\mathrm{M}_{\mathrm{Mm}}\right) \omega_{\mathrm{M}}}=\frac{\mathrm{M}_{\mathrm{M}}}{\mathrm{M}_{\mathrm{M}}+\mathrm{M}_{\mathrm{Mm}}}=\frac{\mathrm{M}_{\mathrm{M}}}{\mathrm{M}_{\mathrm{Mi}}}
\end{gathered}
$$

The motor mechanical efficiency $\eta_{\mathrm{Mm}}$ is a function of torque $\mathrm{M}_{\mathrm{Mm}}$ of mechanical losses in the ,shaft - working chambers" assembly and the shaft loading torque $\mathrm{M}_{\mathrm{M}}$. Therefore, the $\eta_{\mathrm{Mm}}$ efficiency is a function of torque $\mathrm{M}_{\mathrm{M}}$ and shaft rotational speed $\mathrm{n}_{\mathrm{M}}$ and a function of working fluid viscosity $\mathrm{v}$, which influences (apart from $\mathrm{M}_{\mathrm{M}}$ ) the torque $\mathrm{M}_{\mathrm{Mm}}$ of mechanical losses in the „shaft - working chambers” assembly:

$$
\eta_{\mathrm{Mm}}=\mathrm{f}\left(\mathrm{M}_{\mathrm{Mm}}, \mathrm{M}_{\mathrm{M}}\right)=\mathrm{f}\left(\mathrm{M}_{\mathrm{M}}, \mathrm{n}_{\mathrm{M}}, v\right)
$$

because: $\mathrm{M}_{\mathrm{Mm}}=\mathrm{f}\left(\mathrm{M}_{\mathrm{M}}, \mathrm{n}_{\mathrm{M}}, v\right)$.

The motor mechanical efficiency $\eta_{\mathrm{Mm}}$ can be also evaluated from the formula:

$$
\eta_{\mathrm{Mm}}=\frac{2 \Pi \mathrm{M}_{\mathrm{M}}}{\Delta \mathrm{p}_{\mathrm{Mi}} \mathrm{q}_{\mathrm{Mt}}}
$$

However, mechanical efficiency $\eta_{\mathrm{Mm}}$ is not a function of the decrease $\Delta \mathrm{p}_{\mathrm{Mi}}$ of pressure indicated in the motor working chambers and of the motor theoretical capacity $\mathrm{q}_{\mathrm{Mt}}$ per one shaft revolution.

- Intensity $\mathrm{Q}_{\mathrm{Mv}}$ of the motor volumetric losses in the working chambers takes into account internal volumetric losses (between the chamber inlet channel and chamber outlet channel) and external volumetric losses (between chambers and casing and then led out of the casing). The intensity $\mathrm{Q}_{\mathrm{Mv}}$ of motor volumetric losses (with determined theoretical capacity $\mathrm{q}_{\mathrm{Mt}}$ per one shaft revolution) is a function of the decrease $\Delta \mathrm{p}_{\mathrm{Mi}}$ of pressure indicated in the chambers and, to some extent, of the shaft rotational speed $n_{M}$ as well as working fluid viscosity $v$ :

$$
\mathrm{Q}_{\mathrm{Mv}}=\mathrm{f}\left(\Delta \mathrm{p}_{\mathrm{Mi}}, \mathrm{n}_{\mathrm{M}}, \mathrm{v}\right)
$$

The intensity $\mathrm{Q}_{\mathrm{Mv}}$ of volumetric losses in the motor working chambers is a complex function of torque $\mathrm{M}_{\mathrm{M}}$ and motor shaft speed $n_{M}$ and also working fluid viscosity $v$, i.e. of parameters independent of the motor and motor losses. The decrease $\Delta \mathrm{p}_{\mathrm{Mi}}$ of pressure indicated in the chambers, influencing directly $\mathrm{Q}_{\mathrm{Mv}}$ [formula (14)], is a function [formula (6)] of the shaft torque $\mathrm{M}_{\mathrm{M}}$ and of torque $\mathrm{M}_{\mathrm{Mm}}$ of mechanical losses in the ,shaft - working chambers" assembly and, in turn, torque $\mathrm{M}_{\mathrm{Mm}}$ of the losses [formula (2)] is a function of torque $M_{M}$ and of motor shaft speed $n_{M}$ and also of the working fluid viscosity $v$. At the same time, the impact of shaft speed $n_{M}$ and working fluid viscosity $v$ on the intensity $\mathrm{Q}_{\mathrm{Mv}}$ of the volumetric losses in working chambers differs from the impact of $\mathrm{n}_{\mathrm{M}}$ and $v$ on the torque $\mathrm{M}_{\mathrm{Mm}}$ of mechanical losses in the ,shaft - working chambers" assembly. A direct evaluation of the relation of intensity $\mathrm{Q}_{\mathrm{Mv}}$ of volumetric losses in the motor working chambers to the motor shaft torque $M_{M}$ and speed $n_{M}$ and also to the working fluid viscosity $v$ would be unjustified and wrong because it would be under a complex impact of the torque $\mathrm{M}_{\mathrm{Mm}}$ of mechanical losses.

- Power $\Delta \mathrm{P}_{\mathrm{Mv}}$ of the motor volumetric losses, in the working chambers, is a product of decrease $\Delta \mathrm{p}_{\mathrm{Mi}}$ of pressure indicated in the chambers and intensity $\mathrm{Q}_{\mathrm{Mv}}$ of volumetric losses in the chambers (on the assumption that the external volumetric losses are small and negligible from the energy point of view):

$$
\Delta \mathrm{P}_{\mathrm{Mv}}=\Delta \mathrm{p}_{\mathrm{Mi}} \mathrm{Q}_{\mathrm{Mv}}
$$

- Motor capacity $Q_{M}$ required by the motor from the driving fluid must be greater than the product $\mathrm{q}_{\mathrm{Mt}} \mathrm{n}_{\mathrm{M}}$ [theoretical capacity $\mathrm{q}_{\mathrm{Mt}}$ per one shaft resolution and motor shaft rotational speed $n_{M}$ required by the motor driven machine (device)] because of the necessity of balancing also the intensity $\mathrm{Q}_{\mathrm{Mv}}$ of volumetric losses in the motor working chambers. Capacity $Q_{M}$ is equal to the sum of intensity $q_{M t}$ $\mathrm{n}_{\mathrm{M}}$ and intensity $\mathrm{Q}_{\mathrm{Mv}}$ :

$$
\mathrm{Q}_{\mathrm{M}}=\mathrm{q}_{\mathrm{Mt}} \mathrm{n}_{\mathrm{M}}+\mathrm{Q}_{\mathrm{Mv}}
$$


Evaluation of the motor capacity $\mathrm{Q}_{\mathrm{M}}$ (with determined theoretical capacity $\mathrm{q}_{\mathrm{Mt}}$ per one shaft revolution) can be performed with a formula including the motor shaft rotational speed $n_{M}$ required by the motor driven machine and known motor volumetric efficiency $\eta_{\mathrm{Mv}}$ [formula (23)]:

$$
\mathrm{Q}_{\mathrm{M}}=\frac{\mathrm{q}_{\mathrm{Mt}} \mathrm{n}_{\mathrm{M}}}{\eta_{\mathrm{Mv}}}
$$

with: $\eta_{\mathrm{Mv}}=\mathrm{f}\left(\mathrm{Q}_{\mathrm{Mv}}, \mathrm{n}_{\mathrm{M}}\right)=\mathrm{f}\left(\Delta \mathrm{p}_{\mathrm{Mi}}, \mathrm{n}_{\mathrm{M}}, v\right)$

i.e. a formula, where the volumetric efficiency $\eta_{\mathrm{Mv}}$ is determined as a function of parameters influencing the intensity $\mathrm{Q}_{\mathrm{Mv}}$ of volumetric losses in the working chambers and as a function of the motor rotational speed $\mathrm{n}_{\mathrm{M}}$.

- Power $\mathrm{P}_{\mathrm{Mci}}$ of the working fluid absorbed by the motor in working chambers is required by the motor from the driving fluid as a difference between power $\mathrm{p}_{\mathrm{Mli}} \mathrm{Q}_{\mathrm{M}}$ of the fluid inflowing in the working chambers from the inlet channel and power $p_{M 2 i} Q_{M}$ of the fluid outflowing from the chambers to the outlet channel. Assuming that the external volumetric losses are small and negligible from the energy point of view, it may be accepted that the intensity of the outflowing flux is equal to the intensity $Q_{M}$ of the inflowing flux. Therefore, power $\mathrm{P}_{\mathrm{Mci}}$ may be determined as a product of the decrease $\Delta \mathrm{p}_{\mathrm{Mi}}$ of pressure indicated in working chambers and the motor capacity $\mathrm{Q}_{\mathrm{M}}$. Power $\mathrm{P}_{\mathrm{Mci}}$ must be greater than power $\mathrm{P}_{\mathrm{Mi}}$ indicated in the chambers (required by the motor from the driving fluid at the point of conversion (change) of pressure energy of working fluid into the mechanical energy of the "shaft - working chambers" assembly) because of the necessity of balancing also the power $\Delta \mathrm{P}_{\mathrm{Mv}}$ of volumetric losses in the chambers. Power $\mathrm{P}_{\mathrm{Mci}}$ is equal to the sum of power $\mathrm{P}_{\mathrm{Mi}}$ and power $\Delta \mathrm{P}_{\mathrm{Mv}}$ :

$$
\begin{gathered}
\mathrm{P}_{\mathrm{Mci}}=\mathrm{p}_{\mathrm{M} 1 \mathrm{i}} \mathrm{Q}_{\mathrm{M}}-\mathrm{p}_{\mathrm{M} 2 \mathrm{i}} \mathrm{Q}_{\mathrm{M}}= \\
=\Delta \mathrm{p}_{\mathrm{Mi}} \mathrm{Q}_{\mathrm{M}}=\Delta \mathrm{p}_{\mathrm{Mi}}\left(\mathrm{q}_{\mathrm{Mt}} \mathrm{n}_{\mathrm{M}}+\mathrm{Q}_{\mathrm{Mv}}\right)= \\
=\Delta \mathrm{p}_{\mathrm{Mi}} \mathrm{q}_{\mathrm{Mt}} \mathrm{n}_{\mathrm{M}}+\Delta \mathrm{p}_{\mathrm{Mi}} \mathrm{Q}_{\mathrm{Mv}}=\mathrm{P}_{\mathrm{Mi}}+\Delta \mathrm{P}_{\mathrm{Mv}}
\end{gathered}
$$

Power $\mathrm{P}_{\mathrm{Mci}}$ of the working fluid consumed by the motor in working chambers is a sum of useful power $\mathrm{P}_{\mathrm{Mu}}$ [required on the motor shaft by driven machine (device)], power $\Delta \mathrm{P}_{\mathrm{Mm}}$ of mechanical losses in the "shaft - working chambers" assembly and power $\Delta \mathrm{P}_{\mathrm{Mv}}$ of volumetric losses in the motor working chambers:

$$
\mathrm{P}_{\mathrm{Mci}}=\mathrm{P}_{\mathrm{Mu}}+\Delta \mathrm{P}_{\mathrm{Mm}}+\Delta \mathrm{P}_{\mathrm{Mv}}
$$

After replacing in the equation (19) the useful power $\mathrm{P}_{\mathrm{Mu}}$, power $\Delta \mathrm{P}_{\mathrm{Mm}}$ of mechanical losses and power $\Delta \mathrm{P}_{\mathrm{Mv}}$ of volumetric losses by the expressions relating those powers to the parameters and losses deciding of their values, a picture can be obtained of the impact of those parameters and losses on power $\mathrm{P}_{\mathrm{Mci}}$ consumed in the working chambers:

$$
\begin{gathered}
\mathrm{P}_{\mathrm{Mci}}=\mathrm{M}_{\mathrm{M}} \omega_{\mathrm{M}}+\mathrm{M}_{\mathrm{Mm}} \omega_{\mathrm{M}}+\Delta \mathrm{p}_{\mathrm{Mi}} \mathrm{Q}_{\mathrm{Mv}}= \\
=\mathrm{M}_{\mathrm{M}} \omega_{\mathrm{M}}+\mathrm{M}_{\mathrm{Mm}} \omega_{\mathrm{M}}+\frac{2 \Pi\left(\mathrm{M}_{\mathrm{M}}+\mathrm{M}_{\mathrm{Mm}}\right)}{\mathrm{q}_{\mathrm{Mt}}} \mathrm{Q}_{\mathrm{Mv}}= \\
=2 \Pi\left(\mathrm{M}_{\mathrm{M}}+\mathrm{M}_{\mathrm{Mm}}\right)\left(\mathrm{n}_{\mathrm{M}}+\frac{\mathrm{Q}_{\mathrm{Mv}}}{\mathrm{q}_{\mathrm{Mt}}}\right)
\end{gathered}
$$

Power $\mathrm{P}_{\mathrm{Mci}}$ of working fluid consumed by the motor in working chambers can be evaluated by means of a formula expressing the ratio of power $\mathrm{P}_{\mathrm{Mi}}$ indicated in the working chambers to a known volumetric efficiency $\eta_{\mathrm{Mv}}$ of the motor [formula (23)]:

$$
\mathrm{P}_{\mathrm{Mci}}=\frac{\mathrm{P}_{\mathrm{Mi}}}{\eta_{\mathrm{Mv}}}
$$

with: $\eta_{\mathrm{Mv}}=\mathrm{f}\left(\mathrm{Q}_{\mathrm{Mv}}, \mathrm{n}_{\mathrm{M}}\right)=\mathrm{f}\left(\Delta \mathrm{p}_{\mathrm{Mi}}, \mathrm{n}_{\mathrm{M}}, v\right)$

i.e. a formula where volumetric efficiency $\eta_{\mathrm{Mv}}$ is determined as a function of parameters influencing the intensity $\mathrm{Q}_{\mathrm{Mv}}$ of volumetric losses in the working chambers and as a function of the motor rotational speed $n_{M}$

Power $\mathrm{P}_{\mathrm{Mci}}$ of the working fluid consumed by motor in the working chambers can be evaluated also from the known useful power $\mathrm{P}_{\mathrm{Mu}}$ on the motor shaft, known mechanical efficiency $\eta_{\mathrm{Mm}}$ [formula (11)] and known volumetric efficiency $\eta_{\mathrm{Mv}}$ of the motor [formula (23)]:

$$
\mathrm{P}_{\mathrm{Mci}}=\frac{\mathrm{P}_{\mathrm{Mu}}}{\eta_{\mathrm{Mm}} \eta_{\mathrm{Mv}}}
$$

with: $\eta_{\mathrm{Mm}}=\mathrm{f}\left(\mathrm{M}_{\mathrm{Mm}}, \mathrm{M}_{\mathrm{M}}\right)=\mathrm{f}\left(\mathrm{M}_{\mathrm{M}}, \mathrm{n}_{\mathrm{M}}, v\right)$

and: $\eta_{M v}=f\left(Q_{M v}, n_{M}\right)=f\left(\Delta p_{M i}, n_{M}, v\right)$

i.e. a formula where mechanical efficiency $\eta_{\mathrm{Mm}}$ is determined as a function of parameters influencing the torque $\mathrm{M}_{\mathrm{Mm}}$ of mechanical losses in the "shaft - working chambers" assembly and as a function of torque $\mathrm{M}_{\mathrm{M}}$ loading the motor shaft, and the volumetric efficiency $\eta_{\mathrm{Mv}}$ is determined as a function of parameters influencing the intensity $\mathrm{Q}_{\mathrm{Mv}}$ of volumetric losses in the working chambers and of the motor rotational speed $n_{M}$.

- Volumetric efficiency $\eta_{M v}$ of the motor is a ratio of power $\mathrm{P}_{\mathrm{Mi}}$ indicated in the motor working chambers to power $\mathrm{P}_{\mathrm{Mci}}$ of working fluid consumed by the motor in the chambers:

$$
\begin{gathered}
\eta_{\mathrm{Mv}}=\frac{\mathrm{P}_{\mathrm{Mi}}}{\mathrm{P}_{\mathrm{Mci}}}=\frac{\mathrm{P}_{\mathrm{Mi}}}{\mathrm{P}_{\mathrm{Mi}}+\Delta \mathrm{P}_{\mathrm{Mv}}}= \\
=\frac{\Delta \mathrm{p}_{\mathrm{Mi}} \mathrm{q}_{\mathrm{Mt}} \mathrm{n}_{\mathrm{M}}}{\Delta \mathrm{p}_{\mathrm{Mi}} \mathrm{q}_{\mathrm{Mt}} \mathrm{n}_{\mathrm{M}}+\Delta \mathrm{p}_{\mathrm{Mi}} \mathrm{Q}_{\mathrm{Mv}}}= \\
=\frac{\mathrm{q}_{\mathrm{Mt}} \mathrm{n}_{\mathrm{M}}}{\mathrm{q}_{\mathrm{Mt}} \mathrm{n}_{\mathrm{M}}+\mathrm{Q}_{\mathrm{Mv}}}=\frac{\mathrm{q}_{\mathrm{Mt}} \mathrm{n}_{\mathrm{M}}}{\mathrm{Q}_{\mathrm{M}}}
\end{gathered}
$$

The motor volumetric efficiency $\eta_{\mathrm{Mv}}$ (with determined theoretical capacity $\mathrm{q}_{\mathrm{Mt}}$ per one shaft revolution) is a function of intensity $\mathrm{Q}_{\mathrm{Mv}}$ of volumetric losses in the motor and of the motor shaft rotational speed $n_{M}$. Therefore, efficiency $\eta_{M v}$ is a function of the decrease $\Delta \mathrm{p}_{\mathrm{Mi}}$ of pressure indicated in working chambers and a function of the rotational speed $n_{M}$ as well as a function of the working fluid viscosity $v$ (which have an impact on the intensity $\mathrm{Q}_{\mathrm{My}}$ of volumetric losses) and also directly a function of rotational speed $n_{M}$ :

$$
\eta_{\mathrm{Mv}}=\mathrm{f}\left(\mathrm{Q}_{\mathrm{Mv}}, \mathrm{n}_{\mathrm{M}}\right)=\mathrm{f}\left(\Delta \mathrm{p}_{\mathrm{Mi}}, \mathrm{n}_{\mathrm{M}}, \mathrm{v}\right)
$$

because: $\mathrm{Q}_{\mathrm{Mv}}=\mathrm{f}\left(\Delta \mathrm{p}_{\mathrm{Mi}}, \mathrm{n}_{\mathrm{M}}, v\right)$.

- Losses $\Delta p_{M p}$ of working fluid pressure in the motor channels are a sum of two pressure losses i.e. loss $\Delta \mathrm{p}_{\mathrm{Mpl}}$ of pressure in the inlet channel (between the motor inlet point and working chambers) and loss $\Delta \mathrm{p}_{\mathrm{Mp} 2}$ of pressure in the outlet channel (between the working chambers and the motor outlet point). Losses $\Delta \mathrm{p}_{\mathrm{Mp}}$ are a function of motor capacity $\mathrm{Q}_{\mathrm{M}}$ and of working fluid viscosity $v$ :

$$
\Delta \mathrm{p}_{\mathrm{Mp}}=\Delta \mathrm{p}_{\mathrm{Mp} 1}+\Delta \mathrm{p}_{\mathrm{Mp} 2}=\mathrm{f}\left(\mathrm{Q}_{\mathrm{M}}, v\right)
$$

Losses $\Delta \mathrm{p}_{\mathrm{Mp}}$ of working fluid pressure in the motor channels 
are a complex function of the motor shaft speed $n_{M}$ and torque $\mathrm{M}_{\mathrm{M}}$ and the working fluid viscosity $\mathrm{v}$, i.e. parameters independent of the motor and of losses in it. The motor capacity $\mathrm{Q}_{\mathrm{M}}$, having a direct impact on $\Delta \mathrm{p}_{\mathrm{Mp}}$ [formula (14)], is a function [formula (16)] of the shaft rotational speed $n_{M}$ and of intensity of volumetric losses $\mathrm{Q}_{\mathrm{Mv}}$ in the working chambers. The decrease $\Delta \mathrm{p}_{\mathrm{Mi}}$ of pressure indicated in the working chambers, having a direct impact on $\mathrm{Q}_{\mathrm{Mv}}$ [formula (14)], is a function [formula (6)] of the shaft torque $M_{M}$ and of torque $\mathrm{M}_{\mathrm{Mm}}$ of mechanical losses in the „shaft - working chambers" assembly, and the torque $\mathrm{M}_{\mathrm{Mm}}$ of mechanical losses [formula (2)] is in turn a function of the motor shaft torque $\mathrm{M}_{\mathrm{M}}$ and speed $\mathrm{n}_{\mathrm{M}}$ and of the viscosity $v$ of working fluid. At the same time, the impact of working fluid viscosity $v$ on the losses $\Delta \mathrm{p}_{\mathrm{Mp}}$ of fluid pressure in the channels differs from the impact of viscosity $v$ on the intensity $\mathrm{Q}_{\mathrm{Mv}}$ of volumetric losses in the working chambers and from the impact of $v$ on the torque $\mathrm{M}_{\mathrm{Mm}}$ of mechanical losses in the "shaft - working chambers" assembly. Also the impact of shaft speed $\mathrm{n}_{\mathrm{M}}$ on the intensity $\mathrm{Q}_{\mathrm{Mv}}$ of volumetric losses in the working chambers differs from the impact of $n_{M}$ on the torque $\mathrm{M}_{\mathrm{Mm}}$ of mechanical losses in the ,shaft - working chambers" assembly. Direct evaluation of the dependence of pressure losses $\Delta \mathrm{p}_{\mathrm{Mp}}$ of the working fluid in the motor channels on the motor shaft speed $n_{M}$ and torque $M_{M}$ and on the viscosity $v$ of working fluid would be unjustified and wrong, because it would be under a complex impact of the intensity $\mathrm{Q}_{\mathrm{Mv}}$ of volumetric losses in working chambers and of torque $\mathrm{M}_{\mathrm{Mm}}$ of mechanical losses in the ,shaft - working chambers" assembly.

- Power $\Delta \mathrm{P}_{\mathrm{Mp}}$ of pressure losses in the motor, in the motor channels, with the assumption that external volumetric losses are small and negligible from the energy point of view, is a product of the pressure losses $\Delta \mathrm{p}_{\mathrm{Mp}}$ in the channels and the motor capacity $\mathrm{Q}_{\mathrm{M}}$ :

$$
\Delta \mathrm{P}_{\mathrm{Mp}}=\Delta \mathrm{p}_{\mathrm{Mp}} \mathrm{Q}_{\mathrm{M}}
$$

- Decrease $\Delta p_{M}$ of pressure in the motor (with determined theoretical capacity $\mathrm{q}_{\mathrm{Mt}}$ per one shaft revolution), required by the motor from the driving working fluid, must be greater than decrease $\Delta \mathrm{p}_{\mathrm{Mi}}$ of pressure indicated in the working chambers (required by the torque $\mathrm{M}_{\mathrm{Mi}}$ indicated in the chambers) because of the necessity of balancing also the losses $\Delta \mathrm{p}_{\mathrm{Mp}}$ of pressure in the motor channels. Decrease $\Delta \mathrm{p}_{\mathrm{M}}$ is equal to the sum of the indicated decrease $\Delta \mathrm{p}_{\mathrm{Mi}}$ and losses $\Delta \mathrm{p}_{\mathrm{Mp}}$ :

$$
\Delta \mathrm{p}_{\mathrm{M}}=\Delta \mathrm{p}_{\mathrm{Mi}}+\Delta \mathrm{p}_{\mathrm{Mp}}
$$

Replacing in the equation (27) the decrease $\Delta \mathrm{p}_{\mathrm{Mi}}$ of pressure indicated in the working chambers with expression (6), we obtain the dependence of decrease $\Delta p_{M}$ of pressure in the motor on the required torque $\mathrm{M}_{\mathrm{M}}$ loading the motor shaft and on the torque $\mathrm{M}_{\mathrm{Mm}}$ of mechanical losses in the ,,shaft - working chambers" assembly and also on the pressure losses $\Delta \mathrm{p}_{\mathrm{Mp}}$ in the motor channels:

$$
\Delta \mathrm{p}_{\mathrm{M}}=\frac{2 \Pi\left(\mathrm{M}_{\mathrm{M}}+\mathrm{M}_{\mathrm{Mm}}\right)}{\mathrm{q}_{\mathrm{Mt}}}+\Delta \mathrm{p}_{\mathrm{Mp}}
$$

The decrease $\Delta p_{M}$ of pressure in the motor can be evaluated by means of a formula expressing the ratio of decrease $\Delta \mathrm{p}_{\mathrm{Mi}}$ of pressure indicated in the working chambers to the known pressure efficiency $\eta_{\mathrm{Mp}}$ of the motor [formula (37)]:

$$
\begin{gathered}
\Delta \mathrm{p}_{\mathrm{M}}=\frac{\Delta \mathrm{p}_{\mathrm{Mi}}}{\eta_{\mathrm{Mp}}} \\
\text { with: } \eta_{\mathrm{Mp}}=\mathrm{f}\left(\Delta \mathrm{p}_{\mathrm{Mp}}, \Delta \mathrm{p}_{\mathrm{Mi}}\right)=\mathrm{f}\left(\mathrm{Q}_{\mathrm{M}}, \Delta \mathrm{p}_{\mathrm{Mi}}, v\right)
\end{gathered}
$$

i.e. formula where the motor pressure efficiency $\eta_{M p}$ is defined as a function of parameters influencing the losses $\Delta \mathrm{p}_{\mathrm{Mp}}$ of working fluid pressure in the channels and as a function of the decrease $\Delta \mathrm{p}_{\mathrm{Mi}}$ of pressure indicated in the working chambers.

Decrease $\Delta \mathrm{p}_{\mathrm{M}}$ of pressure in the motor can be evaluated also from a known torque $\mathrm{M}_{\mathrm{M}}$ loading the motor shaft, from a known mechanical efficiency $\eta_{\mathrm{Mm}}[$ formula (11)] and a known motor pressure efficiency $\eta_{\mathrm{Mp}}[$ formula (37)]:

$$
\Delta \mathrm{p}_{\mathrm{M}}=\frac{2 \Pi \mathrm{M}_{\mathrm{M}}}{\mathrm{q}_{\mathrm{Mt}} \eta_{\mathrm{Mm}} \eta_{\mathrm{Mp}}}
$$

with: $\eta_{\mathrm{Mm}}=\mathrm{f}\left(\mathrm{M}_{\mathrm{Mm}}, \mathrm{M}_{\mathrm{M}}\right)=\mathrm{f}\left(\mathrm{M}_{\mathrm{M}}, \mathrm{n}_{\mathrm{M}}, v\right)$

and: $\eta_{\mathrm{Mp}}=\mathrm{f}\left(\Delta \mathrm{p}_{\mathrm{Mp}}, \Delta \mathrm{p}_{\mathrm{Mi}}\right)=\mathrm{f}\left(\mathrm{Q}_{\mathrm{M}}, \Delta \mathrm{p}_{\mathrm{Mi}}, v\right)$

i.e. formula, where the mechanical efficiency $\eta_{M m}$ is defined as a function of parameters influencing the torque $\mathrm{M}_{\mathrm{Mm}}$ of mechanical losses in the "shaft - working chambers" assembly and a function of torque $\mathrm{M}_{\mathrm{M}}$ loading the motor shaft and the pressure efficiency $\eta_{\mathrm{Mp}}$ is defined as a function of parameters influencing the losses $\Delta \mathrm{p}_{\mathrm{Mp}}$ of pressure in the channels and as a function of decrease $\Delta \mathrm{p}_{\mathrm{Mi}}$ of pressure indicated in the motor working chambers.

- Working fluid power $\mathrm{P}_{\mathrm{Mc}}$ consumed by the motor must be greater than power $\mathrm{P}_{\mathrm{Mci}}$ (consumed by the motor in the working chambers) because of the necessity of balancing also the power $\Delta \mathrm{P}_{\mathrm{Mp}}$ of pressure losses in the motor channels. Power $\mathrm{P}_{\mathrm{Mc}}$ is equal to the sum of power $\mathrm{P}_{\mathrm{Mci}}$ and power $\Delta \mathrm{P}_{\mathrm{Mp}}$ of the losses. Power $\mathrm{P}_{\mathrm{Mc}}$ is a product of the decrease $\Delta \mathrm{p}_{\mathrm{M}}$ of pressure in the motor and motor capacity $\mathrm{Q}_{\mathrm{M}}$ :

$$
\begin{aligned}
& \mathrm{P}_{\mathrm{Mc}}=\Delta \mathrm{p}_{\mathrm{M}} \mathrm{Q}_{\mathrm{M}}=\left(\Delta \mathrm{p}_{\mathrm{Mi}}+\Delta \mathrm{p}_{\mathrm{Mp}}\right) \mathrm{Q}_{\mathrm{M}}= \\
& =\Delta \mathrm{p}_{\mathrm{Mi}} \mathrm{Q}_{\mathrm{M}}+\Delta \mathrm{p}_{\mathrm{Mp}} \mathrm{Q}_{\mathrm{M}}=\mathrm{P}_{\mathrm{Mci}}+\Delta \mathrm{P}_{\mathrm{Mp}}
\end{aligned}
$$

The working fluid power $\mathrm{P}_{\mathrm{Mc}}$ consumed by the motor is a sum of useful power $\mathrm{P}_{\mathrm{Mu}}$ (required on the motor shaft by the driven machine (device)], power $\Delta \mathrm{P}_{\mathrm{Mm}}$ of mechanical losses in the "shaft - working chambers" assembly, power $\Delta \mathrm{P}_{\mathrm{Mv}}$ of volumetric losses in the working chambers and power $\Delta \mathrm{P}_{\mathrm{Mp}}$ of pressure losses in the motor channels:

$$
\mathrm{P}_{\mathrm{Mc}}=\mathrm{P}_{\mathrm{Mu}}+\Delta \mathrm{P}_{\mathrm{Mm}}+\Delta \mathrm{P}_{\mathrm{Mv}}+\Delta \mathrm{P}_{\mathrm{Mp}}
$$

After replacing in equation (32) the useful power $\mathrm{P}_{\mathrm{Mu}}$ and power $\Delta \mathrm{P}_{\mathrm{Mm}}$ of mechanical losses, power $\Delta \mathrm{P}_{\mathrm{Mv}}$ of volumetric losses and power $\Delta \mathrm{P}_{\mathrm{Mp}}$ of pressure losses with formulae expressing dependence on parameters and losses deciding of the values of those powers, we can obtain a picture of the impact of parameters and losses on the consumed power $\mathrm{P}_{\mathrm{Mc}}$ :

$$
\begin{gathered}
\mathrm{P}_{\mathrm{Mc}}=\mathrm{M}_{\mathrm{M}} \omega_{\mathrm{M}}+\mathrm{M}_{\mathrm{Mm}} \omega_{\mathrm{M}}+\Delta \mathrm{p}_{\mathrm{Mi}} \mathrm{Q}_{\mathrm{Mv}}+\Delta \mathrm{p}_{\mathrm{Mp}} \mathrm{Q}_{\mathrm{M}}= \\
=\mathrm{M}_{\mathrm{M}} \omega_{\mathrm{M}}+\mathrm{M}_{\mathrm{Mm}} \omega_{\mathrm{M}}+\frac{2 \Pi\left(\mathrm{M}_{\mathrm{M}}+\mathrm{M}_{\mathrm{Mm}}\right)}{\mathrm{q}_{\mathrm{Mt}}} \mathrm{Q}_{\mathrm{Mv}}+ \\
+\Delta \mathrm{p}_{\mathrm{Mp}}\left(\mathrm{q}_{\mathrm{Mt}} \mathrm{n}_{\mathrm{M}}+\mathrm{Q}_{\mathrm{Mv}}\right)= \\
=2 \Pi\left(\mathrm{M}_{\mathrm{M}}+\mathrm{M}_{\mathrm{Mm}}\right)\left(\mathrm{n}_{\mathrm{M}}+\frac{\mathrm{Q}_{\mathrm{Mv}}}{\mathrm{q}_{\mathrm{Mt}}}\right)+ \\
+\Delta \mathrm{p}_{\mathrm{Mp}}\left(\mathrm{q}_{\mathrm{Mt}} \mathrm{n}_{\mathrm{M}}+\mathrm{Q}_{\mathrm{Mv}}\right)
\end{gathered}
$$

The expression describing the working fluid power $\mathrm{P}_{\mathrm{Mc}}$ consumed by the motor can be also obtained from the 
product of decrease $\Delta \mathrm{p}_{\mathrm{M}}$ of pressure in the motor [formula (28)] and motor capacity $\mathrm{Q}_{\mathrm{M}}$ [formula (16)]:

$$
\begin{gathered}
\mathrm{P}_{\mathrm{Mc}}=\Delta \mathrm{p}_{\mathrm{M}} \mathrm{Q}_{\mathrm{M}}= \\
=\left[\frac{2 \Pi\left(\mathrm{M}_{\mathrm{M}}+\mathrm{M}_{\mathrm{Mm}}\right)}{\mathrm{q}_{\mathrm{Mt}}}+\Delta \mathrm{p}_{\mathrm{Mp}}\right]\left(\mathrm{q}_{\mathrm{Mt}} \mathrm{n}_{\mathrm{M}}+\mathrm{Q}_{\mathrm{Mv}}\right)
\end{gathered}
$$

Expressions (33) and (34) are equivalent.

Evaluation of the working fluid power $\mathrm{P}_{\mathrm{Mc}}$ consumed by the motor can be performed with a formula expressing the ratio of working fluid power $\mathrm{P}_{\mathrm{Mci}}$ consumed by the motor in the working chambers to the motor pressure efficiency $\eta_{\mathrm{Mp}}[$ formula (37)]:

$$
\mathrm{P}_{\mathrm{Mc}}=\frac{\mathrm{P}_{\mathrm{Mci}}}{\eta_{\mathrm{Mp}}}
$$

with: $\eta_{\mathrm{Mp}}=\mathrm{f}\left(\Delta \mathrm{p}_{\mathrm{Mp}}, \Delta \mathrm{p}_{\mathrm{Mi}}\right)=\mathrm{f}\left(\mathrm{Q}_{\mathrm{M}}, \Delta \mathrm{p}_{\mathrm{Mi}}, v\right)$

i.e. a formula where the pressure efficiency $\eta_{\mathrm{Mp}}$ is defined as a function of parameters influencing the losses $\Delta \mathrm{p}_{\mathrm{Mp}}$ of working fluid pressure in the channels and as a function of decrease $\Delta \mathrm{p}_{\mathrm{Mi}}$ of pressure indicated in the motor working chambers.

The working fluid power $\mathrm{P}_{\mathrm{Mc}}$ consumed by the motor can be evaluated from the known useful power $\mathrm{P}_{\mathrm{Mu}}$ on the motor shaft, a known mechanical efficiency $\eta_{\mathrm{Mm}}$ [formula (11)], known volumetric efficiency $\eta_{\mathrm{Mv}}[$ formula (23)] and known pressure efficiency $\eta_{\mathrm{Mp}}$ [formula (37)] of the motor:

$$
P_{M c}=\frac{P_{M u}}{\eta_{M m} \eta_{M v} \eta_{M p}}
$$

with: $\eta_{\mathrm{Mm}}=\mathrm{f}\left(\mathrm{M}_{\mathrm{Mm}}, \mathrm{M}_{\mathrm{M}}\right)=\mathrm{f}\left(\mathrm{M}_{\mathrm{M}}, \mathrm{n}_{\mathrm{M}}, v\right)$

$\eta_{\mathrm{Mv}}=\mathrm{f}\left(\mathrm{Q}_{\mathrm{Mv}}, \mathrm{n}_{\mathrm{M}}\right)=\mathrm{f}\left(\Delta \mathrm{p}_{\mathrm{Mi}}, \mathrm{n}_{\mathrm{M}}, v\right)$

and: $\eta_{\mathrm{Mp}}=\mathrm{f}\left(\Delta \mathrm{p}_{\mathrm{Mp}}, \Delta \mathrm{p}_{\mathrm{Mi}}\right),=\mathrm{f}\left(\mathrm{Q}_{\mathrm{M}}, \Delta \mathrm{p}_{\mathrm{Mi}}, v\right)$.

In formula (36), the mechanical efficiency $\eta_{\mathrm{Mm}}$ is defined as a function of parameters influencing the torque $M_{M m}$ of mechanical losses in the "shaft - working chambers" assembly and as a function of torque $\mathrm{M}_{\mathrm{M}}$ loading the motor shaft. The volumetric efficiency $\eta_{\mathrm{Mv}}$ is defined as a function of parameters influencing the intensity $\mathrm{Q}_{\mathrm{Mv}}$ of volumetric losses in the working chambers and as a function of the motor shaft rotational speed $\mathrm{n}_{\mathrm{M}}$. The pressure efficiency $\eta_{\mathrm{Mp}}$ is defined as a function of parameters influencing the pressure losses $\Delta \mathrm{p}_{\mathrm{Mp}}$ of working fluid in the channels and as a function of the decrease $\Delta \mathrm{p}_{\mathrm{Mi}}$ of pressure indicated in the motor working chambers.

- The motor pressure efficiency $\eta_{M p}$ is a ratio of the working fluid power $\mathrm{P}_{\mathrm{Mci}}$ consumed by the motor in the working chambers to the power $\mathrm{P}_{\mathrm{Mc}}$ consumed by the motor:

$$
\begin{gathered}
\eta_{\mathrm{Mp}}=\frac{\mathrm{P}_{\mathrm{Mci}}}{\mathrm{P}_{\mathrm{Mc}}}=\frac{\mathrm{P}_{\mathrm{Mci}}}{\mathrm{P}_{\mathrm{Mci}}+\Delta \mathrm{P}_{\mathrm{Mp}}}= \\
=\frac{\Delta \mathrm{p}_{\mathrm{Mi}} \mathrm{Q}_{\mathrm{M}}}{\left(\Delta \mathrm{p}_{\mathrm{Mi}}+\Delta \mathrm{p}_{\mathrm{Mp}}\right) \mathrm{Q}_{\mathrm{M}}}=\frac{\Delta \mathrm{p}_{\mathrm{Mi}}}{\Delta \mathrm{p}_{\mathrm{Mi}}+\Delta \mathrm{p}_{\mathrm{Mp}}}=\frac{\Delta \mathrm{p}_{\mathrm{Mi}}}{\Delta \mathrm{p}_{\mathrm{M}}}
\end{gathered}
$$

Therefore, the pressure efficiency can by presented as a ratio of the decrease $\Delta \mathrm{p}_{\mathrm{Mi}}$ of pressure indicated in the working chambers to the decrease $\Delta \mathrm{p}_{\mathrm{M}}$ of pressure in the motor. The motor pressure efficiency $\eta_{\mathrm{Mp}}$ is a function of losses $\Delta \mathrm{p}_{\mathrm{Mp}}$ of the working fluid pressure in motor channel and decrease $\Delta \mathrm{p}_{\mathrm{Mi}}$ of pressure indicated in the motor working chambers. Therefore, efficiency $\eta_{\mathrm{Mp}}$ is a function of the motor capacity $\mathrm{Q}_{\mathrm{M}}$ and a function of the working fluid viscosity $v$ (which influence the losses $\Delta \mathrm{p}_{\mathrm{Mp}}$ of working fluid pressure in the channels) as well as a function of the decrease $\Delta \mathrm{p}_{\mathrm{Mi}}$ of pressure in the motor working chambers:

$$
\eta_{\mathrm{Mp}}=\mathrm{f}\left(\Delta \mathrm{p}_{\mathrm{Mp}}, \Delta \mathrm{p}_{\mathrm{Mi}}\right)=\mathrm{f}\left(\mathrm{Q}_{\mathrm{M}}, \Delta \mathrm{p}_{\mathrm{Mi}}, v\right)
$$

because: $\Delta \mathrm{p}_{\mathrm{Mp}}=\mathrm{f}\left(\mathrm{Q}_{\mathrm{M}}, v\right)$.

- The motor overall efficiency $\eta_{M}$ is a ratio of the useful power $\mathrm{P}_{\mathrm{Mu}}$ on the motor shaft required by the driven machine (device) to the power $\mathrm{P}_{\mathrm{Mc}}$ consumed by the motor:

$$
\eta_{\mathrm{M}}=\frac{\mathrm{P}_{\mathrm{Mu}}}{\mathrm{P}_{\mathrm{Mc}}}=\frac{\mathrm{M}_{\mathrm{M}} \omega_{\mathrm{M}}}{\Delta \mathrm{p}_{\mathrm{M}} \mathrm{Q}_{\mathrm{M}}}=\frac{2 \Pi \mathrm{M}_{\mathrm{M}} \mathrm{n}_{\mathrm{M}}}{\Delta \mathrm{p}_{\mathrm{M}} \mathrm{Q}_{\mathrm{M}}}
$$

Replacing in formula (39) the power $\mathrm{P}_{\mathrm{Mc}}$ consumed by the motor with equations describing its dependence on the useful power $\mathrm{P}_{\mathrm{Mu}}$ and on the powers $\Delta \mathrm{P}_{\mathrm{Mm}}, \Delta \mathrm{P}_{\mathrm{Mv}}$ and $\Delta \mathrm{P}_{\mathrm{Mp}}$ of the energy losses in the motor (with a determined theoretical capacity $\mathrm{q}_{\mathrm{Mt}}$ per one shaft revolution), we obtain the expressions describing the motor overall efficiency $\eta_{M}$ as a function of the losses:

with reference to equation (32):

$$
\eta_{\mathrm{M}}=\frac{\mathrm{P}_{\mathrm{Mu}}}{\mathrm{P}_{\mathrm{Mc}}}=\frac{\mathrm{P}_{\mathrm{Mu}}}{\mathrm{P}_{\mathrm{Mu}}+\Delta \mathrm{P}_{\mathrm{Mm}}+\Delta \mathrm{P}_{\mathrm{Mv}}+\Delta \mathrm{P}_{\mathrm{Mp}}}
$$

with reference to equation (33):

$$
\eta_{\mathrm{M}}=\frac{2 \Pi \mathrm{M}_{\mathrm{M}} \mathrm{n}_{\mathrm{M}}}{2 \Pi\left(\mathrm{M}_{\mathrm{M}}+\mathrm{M}_{\mathrm{Mm}}\right)\left(\mathrm{n}_{\mathrm{M}}+\frac{\mathrm{Q}_{\mathrm{Mv}}}{\mathrm{q}_{\mathrm{Mt}}}\right)+\Delta \mathrm{p}_{\mathrm{Mp}}\left(\mathrm{q}_{\mathrm{Mt}} \mathrm{n}_{\mathrm{M}}+\mathrm{Q}_{\mathrm{Mv}}\right)}
$$

with reference to equation (34):

$$
\eta_{M}=\frac{2 \Pi M_{M} n_{M}}{\left[\frac{2 \Pi\left(M_{M}+M_{M m}\right)}{\mathrm{q}_{M t}}+\Delta p_{M p}\right]\left(q_{M t} n_{M}+Q_{M v}\right)}
$$

Expressions (41) and (42) are equivalent.

The motor overall efficiency $\eta_{M}$ is therefore a function of torque $\mathrm{M}_{\mathrm{Mm}}$ of mechanical losses in the ,shaft - working chambers" assembly, intensity $\mathrm{Q}_{\mathrm{Mv}}$ of volumetric losses in the working chambers and losses $\Delta \mathrm{p}_{\mathrm{Mp}}$ of pressure in the motor channels. The $\eta_{M}$ efficiency is also a function of the motor shaft torque $M_{M}$ and speed $n_{M}$ required by the driven machine (device):

$$
\eta_{M}=f\left(M_{M m}, Q_{M v}, \Delta p_{M p}, M_{M}, n_{M}\right)
$$

Torque $\mathrm{M}_{\mathrm{Mm}}=\mathrm{f}\left(\mathrm{M}_{\mathrm{M}}, \mathrm{n}_{\mathrm{M}}, v\right)$ of mechanical losses from friction of elements in the motor "shaft - working chambers" assembly is a function of the required torque $\mathrm{M}_{\mathrm{M}}$ loading the motor shaft. In the piston, satellite and vane motors, torque $M_{M m}$ of the losses is also a function of the required speed $n_{M}$ influencing the inertia forces in the "shaft - working chambers" assembly and in effect the forces of friction between those elements. In the piston motors in particular, with working fluid in the casing, the torque $\mathrm{M}_{\mathrm{Mm}}$ of the losses is also a function of the fluid viscosity $v$, which influences the friction between the "shaft - working chambers" assembly elements and the fluid.

Intensity $\mathrm{Q}_{\mathrm{Mv}}=\mathrm{f}\left(\Delta \mathrm{p}_{\mathrm{Mi}}, \mathrm{n}_{\mathrm{M}}, v\right)$ of volumetric losses in the motor working chambers is a function of the decrease $\Delta \mathrm{p}_{\mathrm{Mi}}$ of pressure indicated in the chambers and, to some extent, a function of motor shaft rotational speed $n_{M}$ and also a function of working fluid viscosity $v$.

Losses $\Delta \mathrm{p}_{\mathrm{Mp}}=\mathrm{f}\left(\mathrm{Q}_{\mathrm{M}}, v\right)$ of the working fluid pressure in the motor channels are a function of the motor capacity $Q_{M}$ and of the working fluid viscosity $v$. 
In order to evaluate the dependence of overall efficiency $\eta_{M}$ of the motor (with determined theoretical capacity $\mathrm{q}_{\mathrm{Mt}}$ per one shaft revolution) on parameters independent of the losses in the motor, i.e. evaluate $\eta_{M}$ as a function of the required motor shaft torque $\mathrm{M}_{\mathrm{M}}$ and speed $\mathrm{n}_{\mathrm{M}}$ and also as a function of the working fluid viscosity $v$, a product of the motor mechanical efficiency $\eta_{\mathrm{Mm}}$, volumetric efficiency $\eta_{\mathrm{Mv}}$ and pressure efficiency $\eta_{\mathrm{Mp}}$ must be used:

$$
\eta_{\mathrm{M}}=\mathrm{f}\left(\mathrm{M}_{\mathrm{M}}, \mathrm{n}_{\mathrm{M}}, v\right)=\eta_{\mathrm{Mm}} \eta_{\mathrm{Mv}} \eta_{\mathrm{Mp}}
$$

with:

$$
\eta_{M m}=f\left(M_{M m}, M_{M}\right)=f\left(M_{M}, n_{M}, v\right)
$$

because: $\quad \mathrm{M}_{\mathrm{Mm}}=\mathrm{f}\left(\mathrm{M}_{\mathrm{M}}, \mathrm{n}_{\mathrm{M}}, v\right)$ [equation (12)] $\eta_{\mathrm{Mv}}=\mathrm{f}\left(\mathrm{Q}_{\mathrm{Mv}}, \mathrm{n}_{\mathrm{M}}\right)=\mathrm{f}\left(\Delta \mathrm{p}_{\mathrm{Mi}}, \mathrm{n}_{\mathrm{M}}, v\right)$

because: $Q_{\mathrm{Mv}}=\mathrm{f}\left(\Delta \mathrm{p}_{\mathrm{Mi}}, \mathrm{n}_{\mathrm{M}}, v\right)$ [equation (24)]

and: $\quad \eta_{\mathrm{Mp}}=\mathrm{f}\left(\Delta \mathrm{p}_{\mathrm{Mp}}, \Delta \mathrm{p}_{\mathrm{Mi}}\right)=\mathrm{f}\left(\mathrm{Q}_{\mathrm{M}}, \Delta \mathrm{p}_{\mathrm{Mi}}, v\right)$

because $\quad \Delta \mathrm{p}_{\mathrm{Mp}}=\mathrm{f}\left(\mathrm{Q}_{\mathrm{M}}, v\right)$ [equation (38)].

In the above equation describing the overall efficiency $\eta_{\mathrm{M}}$, mechanical efficiency $\eta_{\mathrm{Mm}}$ is defined as a function of parameters influencing the torque $\mathrm{M}_{\mathrm{Mm}}$ of mechanical losses in the ,shaft - working chambers" assembly and as a function of torque $\mathrm{M}_{\mathrm{M}}$ loading the motor shaft. Volumetric efficiency $\eta_{\mathrm{Mv}}$ is defined as a function of parameters influencing the intensity $\mathrm{Q}_{\mathrm{Mv}}$ of volumetric losses in the working chambers and also as a function of the motor shaft rotational speed $n_{M}$. Pressure efficiency $\eta_{\mathrm{Mp}}$ is defined as a function of parameters influencing the losses $\Delta \mathrm{p}_{\mathrm{Mp}}$ of working fluid pressure in the channels and a function of decrease $\Delta \mathrm{p}_{\mathrm{Mi}}$ of pressure indicated in the motor working chambers.

After replacing in equation (44) $\eta_{\mathrm{Mm}}$ with expression (13), $\eta_{\mathrm{Mv}}$ with expression (23) and $\eta_{\mathrm{Mp}}$ with expression (37), we obtain a formula describing the motor efficiency $\eta_{M}$ as a ratio of useful power $\mathrm{P}_{\mathrm{Mu}}$ to power $\mathrm{P}_{\mathrm{Mc}}$ consumed by the motor, i.e. a formula confirming correctness of the expressions describing $\eta_{\mathrm{Mm}}, \eta_{\mathrm{Mv}}$ and $\eta_{\mathrm{Mp}}$ :

$$
\begin{gathered}
\eta_{\mathrm{M}}=\mathrm{f}\left(\mathrm{M}_{\mathrm{M}}, \mathrm{n}_{\mathrm{M}}, v\right)=\eta_{\mathrm{Mm}} \eta_{\mathrm{Mv}} \eta_{\mathrm{Mp}}= \\
=\frac{2 \Pi \mathrm{M}_{\mathrm{M}}}{\Delta \mathrm{p}_{\mathrm{Mi}} \mathrm{q}_{\mathrm{Mt}}} \frac{\mathrm{q}_{\mathrm{Mt}} \mathrm{n}_{\mathrm{M}}}{\mathrm{Q}_{\mathrm{M}}} \frac{\Delta \mathrm{p}_{\mathrm{Mi}}}{\Delta \mathrm{p}_{\mathrm{M}}}=\frac{2 \Pi \mathrm{M}_{\mathrm{M}} \mathrm{n}_{\mathrm{M}}}{\mathrm{Q}_{\mathrm{M}} \Delta \mathrm{p}_{\mathrm{M}}}=\frac{\mathrm{P}_{\mathrm{Mu}}}{\mathrm{P}_{\mathrm{Mc}}}
\end{gathered}
$$

In equation (45), the required motor capacity $\mathrm{Q}_{\mathrm{M}}$ [equation (17)] is a function:

$$
\mathrm{Q}_{\mathrm{M}}=\frac{\mathrm{q}_{\mathrm{Mt}} \mathrm{n}_{\mathrm{M}}}{\eta_{\mathrm{Mv}}}
$$

with:

because: $Q_{M v}=f\left(\Delta p_{M i}, n_{M}, v\right)$

and the required pressure decrease $\Delta \mathrm{p}_{\mathrm{M}}$ (equation (30)] is a function:

$$
\Delta \mathrm{p}_{\mathrm{M}}=\frac{2 \Pi \mathrm{M}_{\mathrm{M}}}{\mathrm{q}_{\mathrm{Mt}} \eta_{\mathrm{Mm}} \eta_{\mathrm{Mp}}}
$$

with:

because:

$$
\eta_{M m}=f\left(M_{M m}, M_{M}\right)=f\left(M_{M}, n_{M}, v\right)
$$

and:

$$
\eta_{\mathrm{Mp}}=\mathrm{f}\left(\Delta \mathrm{p}_{\mathrm{Mp}}, \Delta \mathrm{p}_{\mathrm{Mi}}\right)=\mathrm{f}\left(\mathrm{Q}_{\mathrm{M}}, \Delta \mathrm{p}_{\mathrm{Mi}}, v\right)
$$

because: $\Delta \mathrm{p}_{\mathrm{Mp}}=\mathrm{f}\left(\mathrm{Q}_{\mathrm{M}}, v\right)$.

After replacing in equation (44) $\eta_{\mathrm{Mm}}$ with formula (11), $\eta_{\mathrm{Mv}}$ with formula (23) and $\eta_{\mathrm{Mp}}$ with formula (37), we obtain an expression describing the efficiency $\eta_{M}$ as a product of individual efficiencies described by losses and parameters deciding of their values and where at the same time $\Delta \mathrm{p}_{\mathrm{Mi}}$ and $\mathrm{Q}_{\mathrm{M}}$ are functions of the losses.

$$
\begin{gathered}
\eta_{M}=f\left(M_{M}, n_{M}, v\right)=\eta_{M m} \eta_{M v} \eta_{M p}= \\
=\frac{M_{M}}{M_{M}+M_{M m}} \frac{q_{M t} n_{M}}{q_{M t} n_{M}+Q_{M v}} \frac{\Delta p_{M i}}{\Delta p_{M i}+\Delta p_{M p}}
\end{gathered}
$$

where: $\mathrm{M}_{\mathrm{Mm}}=\mathrm{f}\left(\mathrm{M}_{\mathrm{M}}, \mathrm{n}_{\mathrm{M}}, v\right)$ [equation (2)]

$\mathrm{Q}_{\mathrm{Mv}}=\mathrm{f}\left(\Delta \mathrm{p}_{\mathrm{Mi}}, \mathrm{n}_{\mathrm{M}}, \mathrm{v}\right)$ [equation (14)]

$\Delta \mathrm{p}_{\mathrm{Mp}}=\mathrm{f}\left(\mathrm{Q}_{\mathrm{M}}, v\right)$ [equation (25)]

with: $\quad \Delta \mathrm{p}_{\mathrm{Mi}}=\frac{2 \Pi\left(\mathrm{M}_{\mathrm{M}}+\mathrm{M}_{\mathrm{Mm}}\right)}{\mathrm{q}_{\mathrm{Mt}}}$ [equation (6)]

and: $\quad Q_{M}=q_{M t} n_{M}+Q_{M v}$ [equation (16)].

Decrease $\Delta \mathrm{p}_{\mathrm{Mi}}$ of pressure indicated in the working chambers [equation (6)] is a function of the loading torque $\mathrm{M}_{\mathrm{M}}$ and torque $\mathrm{M}_{\mathrm{Mm}}$ of mechanical losses in the ,shaft - working chambers” assembly. Capacity $\mathrm{Q}_{\mathrm{M}}$ in the motor channels [equation (16)] is a function of motor shaft speed $n_{M}$ and the intensity $Q_{M v}$ of volumetric losses in the working chambers.

Formula (46) shows a direct dependence of the torque $\mathrm{M}_{\mathrm{Mm}}$ of mechanical losses in the ,shaft - working chambers” assembly on the torque $\mathrm{M}_{\mathrm{M}}$ and on the motor shaft rotational speed $n_{M}$ as well as on the working fluid viscosity $v$.

Formula (46) presents a complex dependence of the intensity $\mathrm{Q}_{\mathrm{Mv}}$ of volumetric losses in the working chambers on the shaft loading torque $\mathrm{M}_{\mathrm{M}}$ and on the torque $\mathrm{M}_{\mathrm{Mm}}$ of mechanical losses in the ,shaft - working chambers" assembly (decrease $\Delta \mathrm{p}_{\mathrm{Mi}}$ of pressure indicated in the working chambers depends on $\mathrm{M}_{M}$ and $\mathrm{M}_{\mathrm{Mm}}$ and has direct impact on $\mathrm{Q}_{\mathrm{Mv}}$ ) and also on the shaft speed $\mathrm{n}_{\mathrm{M}}$ (influencing in diversified way the torque $\mathrm{M}_{\mathrm{Mm}}$ of mechanical losses and intensity $\mathrm{Q}_{\mathrm{Mv}}$ of volumetric losses). The intensity $\mathrm{Q}_{\mathrm{Mv}}$ of volumetric losses depends on diversified impact of the working fluid viscosity $v$ : indirectly by impact of $v$ on the torque $\mathrm{M}_{\mathrm{Mm}}$ of mechanical losses in the ,shaft - working chambers" assembly and directly by impact of $v$ on intensity $\mathrm{Q}_{\mathrm{Mv}}$ of losses in the chambers.

Formula (46) presents also a complex dependence of losses $\Delta \mathrm{p}_{\mathrm{Mp}}$ of working fluid pressure in the channels on the shaft rotational speed $\mathrm{n}_{\mathrm{M}}$ and on intensity $\mathrm{Q}_{\mathrm{Mv}}$ of volumetric losses in the working chambers. The intensity $\mathrm{Q}_{\mathrm{Mv}}$ of losses influences the motor capacity $Q_{M}$ [equation (16)] and at the same time $Q_{M v}$ depends in a complex way on the shaft loading torque $\mathrm{M}_{\mathrm{M}}$ and on the torque $\mathrm{M}_{\mathrm{Mm}}$ of mechanical losses in the ,shaft - working chambers" assembly. Pressure losses $\Delta \mathrm{p}_{\mathrm{Mp}}$ in the channel are also dependent on the diversified impact of the working fluid viscosity $v$ : indirectly by impact of $v$ on the torque $\mathrm{M}_{\mathrm{Mm}}$ of mechanical losses in the ,shaft - working chambers" assembly and by impact of $v$ on the intensity $\mathrm{Q}_{\mathrm{Mv}}$ of volumetric losses in the working chambers and directly by impact of $v$ on the losses $\Delta \mathrm{p}_{\mathrm{Mp}}$ of pressure in the channels.

\section{ANALYSIS OF THE PRESENTED DEFINITIONS AND RELATIONS}

1. The power $\mathrm{P}_{\mathrm{Mc}}$ consumed by the motor is a sum of motor shaft useful power $\mathrm{P}_{\mathrm{Mu}}$ and powers of three different energy losses in the motor. The losses occur in series increasing power stream in the opposite direction to the direction of power flow. In effect, the power stream in the motor increases from the shaft useful power $\mathrm{P}_{\mathrm{Mu}}$ to the working fluid power $\mathrm{P}_{\mathrm{Mc}}$ consumed by the motor:

$$
\mathrm{P}_{\mathrm{Mc}}=\mathrm{P}_{\mathrm{Mu}}+\Delta \mathrm{P}_{\mathrm{Mm}}+\Delta \mathrm{P}_{\mathrm{Mv}}+\Delta \mathrm{P}_{\mathrm{Mp}}
$$

Mechanical losses (and power $\Delta \mathrm{P}_{\mathrm{Mm}}$ ) occur in the „shaft - working chambers" assembly, volumetric losses (and power $\Delta \mathrm{P}_{\mathrm{Mv}}$ ) occur in the working chambers, pressure losses (and power $\Delta \mathrm{P}_{\mathrm{Mp}}$ ) occur in the motor channels. 
2. Figure 1 presents a diagram of the direction of increasing power stream in a hydraulic motor. Direction of the increase of power stream is opposite to the direction of power flow in the motor. The diagram replaces the Sankey diagram of distribution of power flowing in a power transmission system. The use of Sankey diagram for description of power stream in the power transmission systems is a basic cause of errors in evaluation of losses in the power flow. The Sankey diagram suggests determination of losses in a system as a function of input parameters of that system. The suggestion can be noticed in the method of hydraulic motor investigations and in the related evaluations of losses and the motor energy efficiency. But the input parameters of the system depend on the losses.

3. Torque $\mathrm{M}_{\mathrm{Mm}}$ of mechanical losses in the ,shaft - working chambers" assembly should be evaluated as a function $\mathrm{M}_{\mathrm{Mm}}$ $=\mathrm{f}\left(\mathrm{M}_{\mathrm{M}}, \mathrm{n}_{\mathrm{M}}, v\right)$, i.e. as a function of the motor shaft loading torque $M_{M}$ and the shaft rotational speed $n_{M}$ and also as a function of a working fluid viscosity $v$.

The picture of torque $\mathrm{M}_{\mathrm{Mm}}$ of mechanical losses in the motor, presented in literature and in the industrial practice as a function $\mathrm{M}_{\mathrm{Mm}}=\mathrm{f}\left(\Delta \mathrm{p}_{\mathrm{M}}, \mathrm{n}_{\mathrm{M}}, v\right)$, i.e. as a direct dependence on the decrease $\Delta \mathrm{p}_{\mathrm{M}}$ of pressure in the motor, is incorrect because it bears the impact of the mechanical losses and also of volumetric losses in the working chambers and pressure losses in the motor channels.

4. Intensity $\mathrm{Q}_{\mathrm{Mv}}$ of volumetric losses in the motor working chambers should be evaluated as a function $\mathrm{Q}_{\mathrm{Mv}}=\mathrm{f}\left(\Delta \mathrm{p}_{\mathrm{Mi}}\right.$, $\left.\mathrm{n}_{\mathrm{M}}, v\right)$, i.e. a function of decrease $\Delta \mathrm{p}_{\mathrm{Mi}}$ of pressure indicated in the working chambers and of motor shaft rotational speed $\mathrm{n}_{\mathrm{M}}$ and also as a function of the working fluid viscosity $v$. The picture of intensity $\mathrm{Q}_{\mathrm{Mv}}$ of volumetric losses, presented in literature and in industrial practice as a function $\mathrm{Q}_{\mathrm{Mv}}=$ $\mathrm{f}\left(\Delta \mathrm{p}_{\mathrm{M}}, \mathrm{n}_{\mathrm{M}}, v\right)$, i.e. as a direct dependence on the decrease $\Delta \mathrm{p}_{\mathrm{M}}$ of pressure in the motor, is incorrect, because it bears the impact of the pressure losses in the motor channels.

Similarly, the picture of intensity $\mathrm{Q}_{\mathrm{Mv}}$ of volumetric losses as a function $\mathrm{Q}_{\mathrm{MV}}=\mathrm{f}\left(\mathrm{M}_{\mathrm{M}}, \mathrm{n}_{\mathrm{M}}, v\right)$, i.e. as a direct dependence on the motor shaft loading torque $\mathrm{M}_{\mathrm{M}}$, is also incorrect, because it bears the impact of the mechanical losses in the „shaft - working chambers" assembly.

5. Pressure losses $\Delta \mathrm{p}_{\mathrm{Mp}}$ in the motor channels should be evaluated as a function $\Delta \mathrm{p}_{\mathrm{Mp}}=\mathrm{f}\left(\mathrm{Q}_{\mathrm{M}}, v\right)$, i. e. a function of motor capacity $\mathrm{Q}_{\mathrm{M}}$ and of working fluid viscosity $v$.

The picture of pressure losses $\Delta \mathrm{p}_{\mathrm{Mp}}$, presented sometimes in literature and in the industrial practice as a function $\Delta \mathrm{p}_{\mathrm{Mp}}$ $=\mathrm{f}\left(\mathrm{n}_{\mathrm{M}}, \mathrm{v}\right)$, i.e. as a direct dependence on the motor shaft rotational speed $\mathrm{n}_{\mathrm{M}}$, is incorrect because it bears the impact of mechanical losses in the "shaft - working chambers" assembly and the impact of volumetric losses in the motor working chambers.

6. The torque $M_{M m}$ of mechanical losses in the "shaft - working chambers" assembly and the so called ,torque" of pressure losses $\Delta \mathrm{p}_{\mathrm{Mp}}$ in the motor channels cannot make up a "sum" and also that „sum" cannot be evaluated as directly dependent on the same chosen parameters (which is practiced in literature and in industry), because those losses are of different character and are dependent on different parameters $\left[\mathrm{M}_{\mathrm{Mm}}=\mathrm{f}\left(\mathrm{M}_{\mathrm{M}}, \mathrm{n}_{\mathrm{M}}, v\right), \Delta \mathrm{p}_{\mathrm{Mp}}=\mathrm{f}\left(\mathrm{Q}_{\mathrm{M}}, v\right)\right]$.

7. The impact of working fluid viscosity $v$ on:

- torque $\mathrm{M}_{\mathrm{Mm}}$ of mechanical losses in the ,shaft - working chambers" motor assembly

- intensity $\mathrm{Q}_{\mathrm{Mv}}$ of volumetric losses in the motor working chambers

- pressure losses $\Delta \mathrm{p}_{\mathrm{Mp}}$ in the motor channels

is differentiated.
The dependence of particular kinds of losses on the working fluid viscosity $v$ should be presented in expressions describing dependence of those losses on other parameters which have a direct impact on them $\left[\mathrm{M}_{\mathrm{Mm}}=\mathrm{f}\left(\mathrm{M}_{\mathrm{M}}, \mathrm{n}_{\mathrm{M}}, v\right)\right.$, $\left.\mathrm{Q}_{\mathrm{Mv}}=\mathrm{f}\left(\Delta \mathrm{p}_{\mathrm{Mi}}, \mathrm{n}_{\mathrm{M}}, v\right), \Delta \mathrm{p}_{\mathrm{Mp}}=\mathrm{f}\left(\mathrm{Q}_{\mathrm{M}}, v\right)\right]$.

8. The overall efficiency of the motor (with determined theoretical capacity $\mathrm{q}_{\mathrm{Mt}}$ per one shaft revolution), in the $\left(0 \leq \bar{\omega}_{\mathrm{M}}\left\langle\bar{\omega}_{\mathrm{M} \max }, 0 \leq \overline{\mathrm{M}}_{\mathrm{M}}\left\langle\overline{\mathrm{M}}_{\mathrm{M} \max }\right)\right.\right.$ range of hydraulic motor shaft speed and torque coefficients and in the $v_{\min } \leq v \leq v_{\max }$ range of working fluid viscosity, must be evaluated only as a function $\eta_{M}=f\left(M_{M}, n_{M}, v\right)$, i.e. as a function of the required motor shaft torque $M_{M}$, required shaft rotational speed $n_{M}$ and as a function of the working fluid viscosity $v$. Torque $M_{M}$ and speed $n_{M}$ are parameters required by the motor driven machine (device), independent of the motor and of the motor losses. The working fluid viscosity $v$ is also independent of the motor and of the motor losses. At the same time those parameters $\left(\mathrm{M}_{\mathrm{M}}, \mathrm{n}_{\mathrm{M}}, v\right)$, in a direct or indirect way, have an impact on the motor mechanical, volumetric and pressure losses and also on the internal parameters deciding of the losses: on pressure decrease $\Delta \mathrm{p}_{\mathrm{Mi}}$ indicated in the working chambers and deciding of the capacity $\mathrm{Q}_{\mathrm{Mv}}$ of volumetric losses in the working chambers as well as on the motor capacity $\mathrm{Q}_{\mathrm{M}}$ directly deciding of the pressure losses $\Delta \mathrm{p}_{\mathrm{Mp}}$ in the motor channels.

9. The motor overall efficiency $\eta_{\mathrm{M}}$, as a function of the motor shaft torque $M_{M}$ and speed $n_{M}$ and as a function of the working fluid viscosity $v$, is a product of the motor mechanical efficiency $\eta_{\mathrm{Mm}}$, volumetric efficiency $\eta_{\mathrm{Mv}}$ and pressure efficiency $\eta_{\mathrm{Mp}}$ :

$$
\eta_{\mathrm{M}}=\mathrm{f}\left(\mathrm{M}_{\mathrm{M}}, \mathrm{n}_{\mathrm{M}}, v\right)=\frac{\mathrm{P}_{\mathrm{Mu}}}{\mathrm{P}_{\mathrm{Mc}}}=\eta_{\mathrm{Mm}} \eta_{\mathrm{Mv}} \eta_{\mathrm{Mp}}
$$

Each of the three efficiencies, as a factor of the product describing the overall efficiency, is evaluated as a function of parameters having a direct impact on the respective losses and as a function of a parameter to which those losses are ,added".

10. The mechanical efficiency:

$$
\eta_{\mathrm{Mm}}=\frac{\mathrm{P}_{\mathrm{Mu}}}{\mathrm{P}_{\mathrm{Mi}}}=\frac{\mathrm{M}_{\mathrm{M}}}{\mathrm{M}_{\mathrm{M}}+\mathrm{M}_{\mathrm{Mm}}}=\mathrm{f}\left(\mathrm{M}_{\mathrm{M}}, \mathrm{n}_{\mathrm{M}}, v\right)
$$

must be evaluated as a function of parameters which have a direct impact on the torque $\mathrm{M}_{\mathrm{Mm}}=\mathrm{f}\left(\mathrm{M}_{\mathrm{M}}, \mathrm{n}_{\mathrm{M}}, v\right)$ of mechanical losses in the "shaft - working chambers" assembly, i.e. a function of the required motor shaft torque $\mathrm{M}_{\mathrm{M}}$ and a function of the required shaft rotational speed $\mathrm{n}_{\mathrm{M}}$ as well as a function of the working fluid viscosity $v$. At the same time, the mechanical efficiency $\eta_{\mathrm{Mm}}$ is directly a function of the shaft torque $\mathrm{M}_{\mathrm{M}}$ because the torque $\mathrm{M}_{\mathrm{Mm}}$ of mechanical losses is ,added" to the torque $\mathrm{M}_{\mathrm{M}}$, causing decrease of power transmission efficiency in the assembly.

11. The volumetric efficiency:

$$
\eta_{\mathrm{Mv}}=\frac{\mathrm{P}_{\mathrm{Mi}}}{\mathrm{P}_{\mathrm{Mci}}}=\frac{\mathrm{q}_{\mathrm{Mt}} \mathrm{n}_{\mathrm{M}}}{\mathrm{q}_{\mathrm{Mt}} \mathrm{n}_{\mathrm{M}}+\mathrm{Q}_{\mathrm{Mv}}}=\mathrm{f}\left(\Delta \mathrm{p}_{\mathrm{Mi}}, \mathrm{n}_{\mathrm{M}}, v\right)
$$

must be evaluated as a function of parameters which have a direct impact on the intensity $\mathrm{Q}_{\mathrm{Mv}}$ of volumetric losses in the working chambers, i.e. a function of pressure decrease $\Delta \mathrm{p}_{\mathrm{Mi}}$ indicated in the chambers and as a function of the required motor shaft rotational speed $n_{M}$ as well as a function of the working fluid viscosity $v$. At the same time, the volumetric efficiency $\eta_{\mathrm{Mv}}$ is directly a function of the shaft rotational speed $n_{M}$, because the intensity 


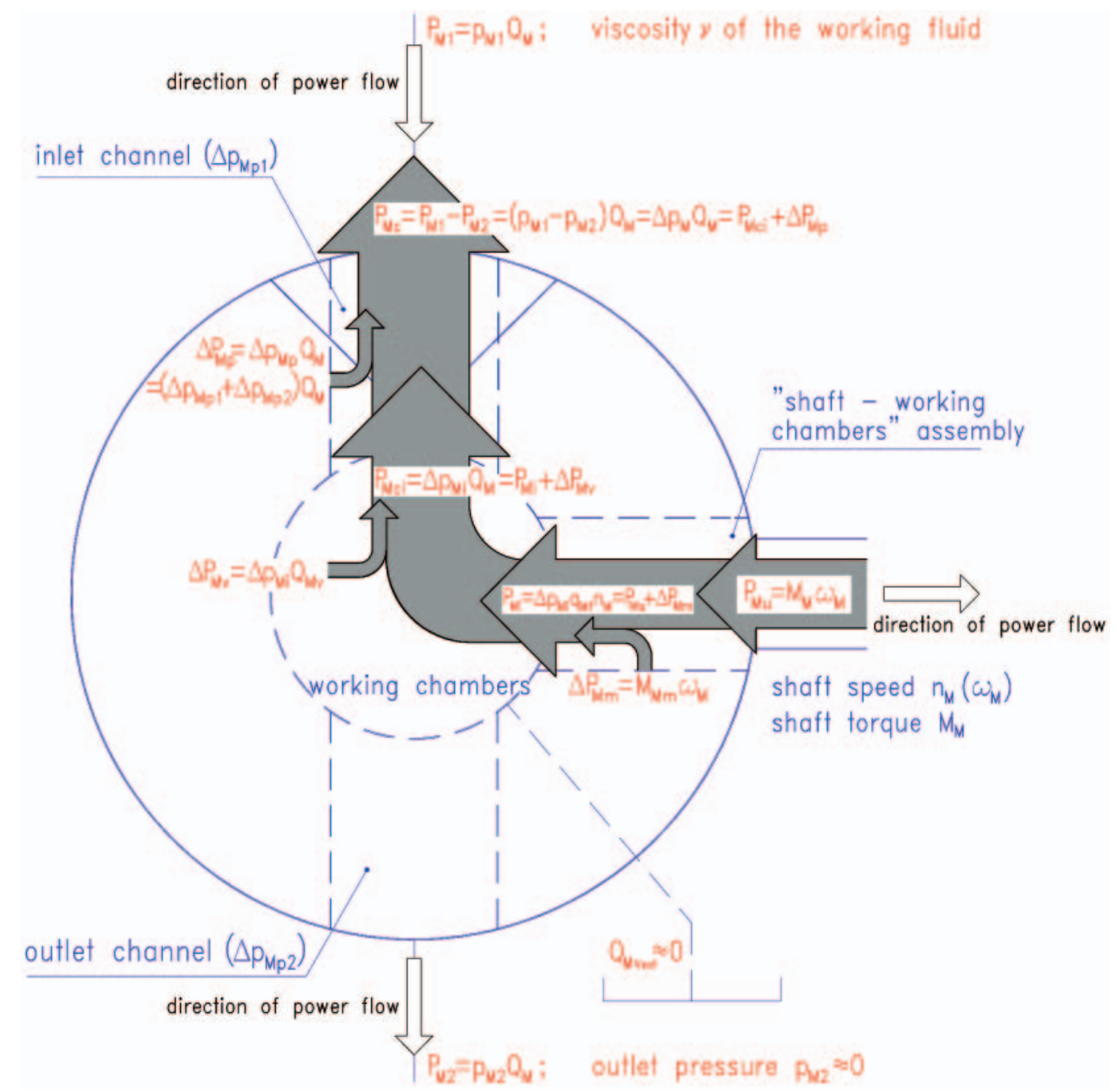

Fig. 1. Diagram of the direction of increasing power stream in a rotational hydraulic motor; direction of the increase of power stream is opposite to the direction of power flow in the motor. Power stream increases from the motor useful power $P_{\text {Mu }}$ required on the motor shaft by the driven machine (device) to power $P$ consumed and required by the motor from the working fluid. The increase of power stream is an effect of the power of losses in the motor: power $\Delta P_{M m}$ of mechanical losses in the , shaft-working chambers” assembly, power $\Delta P_{M v}$ of volumetric losses in the working chambers and power $\Delta P_{M}$ of pressure losses in the motor channels. Powers $\Delta P_{M m}, \Delta P_{M v}$ and $\Delta P_{M p}$ of the losses are functions of the output parameters of the motor assembly where the losses occur and diversified functions of the working fluid viscosity v: power $\Delta P_{\text {um }}$ of mechanical losses is a function of torque $M_{M}$ and shaft speed $n_{M}$ ( $\omega_{M}$ ) required of the motor by the driven machine (device) and a function of the working fluid viscosity $v$, power $\Delta P_{M v}$ of volumetric losses is a function of the decrease $\Delta p_{M i}$ of pressure indicated in working chambers (torque $M_{M i}$ indicated in the chambers) and of the shaft rotational speed $n_{M}$ as well as a function of the working fluid viscosity $v$, power $\Delta P_{M p}$ of pressure losses is a function of motor capacity $Q_{M}$ and of the working fluid viscosity $v$. Power $P_{M i}$ indicated in the working chambers: $P_{M i}=P_{M u}+\Delta P_{M m}{ }^{M p}$ power $P_{M c i}$ of the working fluid consumed in the working chambers: $P_{M c i}=P_{M u}+\Delta P_{M m}+\Delta P_{M v}$ power $P_{M c}$ of the working fluid consumed by the motor: $P_{M c}^{M m}=P_{M u}+\Delta P_{M m}+\Delta P_{M v}+\Delta P_{M p}$. The diagram replaces the Sankey diagram of distribution of power in transmission systems, causing incorrect loss evaluation during the hydraulic motor energy investigations.

$\mathrm{Q}_{\mathrm{Mv}}$ of volumetric losses is ,added" to the product of theoretical capacity $\mathrm{q}_{\mathrm{Mt}}$ per one shaft revolution and speed $\mathrm{n}_{\mathrm{M}}$, causing decrease of power transmission efficiency in the chambers.

If we wish to present the motor volumetric efficiency $\eta_{\mathrm{Mv}}$ as a factor in the product $\eta_{\mathrm{Mm}} \eta_{\mathrm{Mv}} \eta_{\mathrm{Mp}}$ describing the motor overall efficiency $\eta_{\mathrm{M}}$, i.e. to present $\eta_{\mathrm{Mv}}$ as a complex dependence on the parameters $\left(\mathrm{M}_{\mathrm{M}}, \mathrm{n}_{\mathrm{M}}, v\right)$ describing the overall efficiency $\eta_{\mathrm{M}}$ and as a dependence on the mechanical losses in the motor, the intensity $\mathrm{Q}_{\mathrm{Mv}}=\mathrm{f}\left(\Delta \mathrm{p}_{\mathrm{Mi}}, \mathrm{n}_{\mathrm{M}}, v\right)$ of volumetric losses in the chambers should be determined with:

$$
\Delta \mathrm{p}_{\mathrm{Mi}}=\frac{2 \Pi\left(\mathrm{M}_{\mathrm{M}}+\mathrm{M}_{\mathrm{Mm}}\right)}{\mathrm{q}_{\mathrm{Mt}}}
$$

and with torque $\mathrm{M}_{\mathrm{Mm}}$ of mechanical losses in the ,shaft - working chambers" assembly as a function of $\mathrm{M}_{\mathrm{Mm}}=\mathrm{f}$ $\left(\mathrm{M}_{\mathrm{M}}, \mathrm{n}_{\mathrm{M}}, \mathrm{v}\right)$.
12. The pressure efficiency:

$$
\eta_{\mathrm{Mp}}=\frac{\mathrm{P}_{\mathrm{Mci}}}{\mathrm{P}_{\mathrm{Mc}}}=\frac{\Delta \mathrm{p}_{\mathrm{Mi}}}{\Delta \mathrm{p}_{\mathrm{Mi}}+\Delta \mathrm{p}_{\mathrm{Mp}}}=\mathrm{f}\left(\Delta \mathrm{p}_{\mathrm{Mi}}, \mathrm{Q}_{\mathrm{M}}, v\right)
$$

must be evaluated as a function of parameters which have a direct impact on the pressure losses $\Delta \mathrm{p}_{\mathrm{Mp}}$ in the motor channels, i.e. as a function of the motor capacity $Q_{M}$ and a function of the working fluid viscosity $v$. At the same time, the pressure efficiency $\eta_{\mathrm{Mp}}$ is directly a function of the pressure decrease $\Delta \mathrm{p}_{\mathrm{Mi}}$ indicated in the motor working chambers, because pressure losses $\Delta \mathrm{p}_{\mathrm{Mp}}$ in the motor channels are ,added" to the pressure decrease $\Delta \mathrm{p}_{\mathrm{Mi}}$, causing decrease of power transmission efficiency in the channels.

If we wish to present the motor pressure efficiency $\eta_{\mathrm{Mp}}$ as a factor in the product $\eta_{\mathrm{Mm}} \eta_{\mathrm{Mv}} \eta_{\mathrm{Mp}}$ describing the motor overall efficiency $\eta_{M}$, i.e. to present $\eta_{M p}$ as a complex dependence on the parameters $\left(\mathrm{M}_{\mathrm{M}}, \mathrm{n}_{\mathrm{M}}, v\right)$ describing the 
overall efficiency $\eta_{\mathrm{M}}$ and as a dependence on the mechanical and volumetric losses in the motor, the pressure losses $\Delta \mathrm{p}_{\mathrm{Mp}}=\mathrm{f}\left(\mathrm{Q}_{\mathrm{M}}, v\right)$ in the channels should be determined with $\mathrm{Q}_{\mathrm{M}}=\mathrm{q}_{\mathrm{Mt}} \mathrm{n}_{\mathrm{M}}+\mathrm{Q}_{\mathrm{My}}$, the intensity $\mathrm{Q}_{\mathrm{Mv}}=\mathrm{f}\left(\Delta \mathrm{p}_{\mathrm{Mi}}, \mathrm{n}_{\mathrm{M}}, v\right)$ of volumetric losses in the chambers should be determined with:

$$
\Delta \mathrm{p}_{\mathrm{Mi}}=\frac{2 \Pi\left(\mathrm{M}_{\mathrm{M}}+\mathrm{M}_{\mathrm{Mm}}\right)}{\mathrm{q}_{\mathrm{Mt}}}
$$

and with torque $\mathrm{M}_{\mathrm{Mm}}$ of mechanical losses in the ,shaft - working chambers" assembly determined as a function of $\mathrm{M}_{\mathrm{Mm}}=\mathrm{f}\left(\mathrm{M}_{\mathrm{M}}, \mathrm{n}_{\mathrm{M}}, v\right)$.

13. Therefore, the picture of the characteristics of overall efficiency as a product $\eta_{M m} \eta_{M v} \eta_{M p}$ of efficiencies correctly described by the characteristics of mechanical efficiency $\eta_{M}=f\left(M_{M}, n_{M}, v\right)$, volumetric efficiency $\eta_{M v}=f\left(\Delta p_{M i}, n_{M}, v\right)$ and pressure efficiency $\eta_{\mathrm{Mp}}=\mathrm{f}\left(\Delta \mathrm{p}_{\mathrm{Mi}}, \mathrm{Q}_{\mathrm{M}}, v\right)$ is complex.

\section{CONCLUSIONS}

1. The methods of investigation of the rotational hydraulic motor losses and energy efficiency, used in the scientific research and in industrial practice, give incorrect results because:

- losses and efficiencies are evaluated as functions of parameters which depend on those losses or which have no direct impact on the losses,

- the mechanical, volumetric and pressure losses and the corresponding efficiencies are presented as directly dependent on the same parameters, although each of those losses is a function of different parameters and is a different function of the working fluid viscosity $v$.

2. In the investigations of the hydraulic motor (pump and a hydrostatic transmission system) losses and energy efficiency it is necessary to use as a guide the diagram of the direction of increasing power stream from the hydraulic motor shaft to the pump shaft.

3. The complex method of evaluation of the motor overall efficiency $\eta_{M}=f\left(M_{M}, n_{M}, v\right)$ as a product $\eta_{M m} \eta_{M v} \eta_{M p}$ of three efficiencies correctly described by the characteristics of mechanical efficiency $\eta_{\mathrm{Mm}}=\mathrm{f}\left(\mathrm{M}_{\mathrm{M}}, \mathrm{n}_{\mathrm{M}}, v\right)$, volumetric efficiency $\eta_{\mathrm{Mv}}=\mathrm{f}\left(\Delta \mathrm{p}_{\mathrm{Mi}}, \mathrm{n}_{\mathrm{M}}, \mathrm{v}\right)$ and pressure efficiency $\eta_{\mathrm{Mp}}=$ $\mathrm{f}\left(\Delta \mathrm{p}_{\mathrm{Mi}}, \mathrm{Q}_{\mathrm{M}}, \mathrm{v}\right)$ should be replaced by a method of evaluation of the motor efficiency based on the defined coefficients $\mathrm{k}_{\mathrm{i}}$ of the motor and the motor driving system energy losses. The proposed motor efficiency evaluation is performed as a part of the energy efficiency evaluation of the hydrostatic driving system where the motor is used.

4. The evaluation method of the hydraulic motor (and also of the pump and of the hydrostatic driving system) energy efficiency is based on the mathematical models of losses where each type of losses is a function of parameters influencing directly the losses and independent of those losses.

Evaluated are the loss coefficients $\mathrm{k}_{\mathrm{i}}$ relating the hydraulic motor (pump and system) mechanical, volumetric and pressure losses to the reference values: driving system nominal pressure $\mathrm{p}_{\mathrm{n}}$, pump theoretical capacity $\mathrm{Q}_{\mathrm{pt}}$, motor theoretical rotational speed $\mathrm{n}_{\mathrm{Mt}}$ and theoretical torque $\mathrm{M}_{\mathrm{Mt}}$. The loss coefficient $\mathrm{k}_{\mathrm{i}}$ are determined at the working fluid reference viscosity $v_{n}$. Also the impact is determined of the viscosity ratio $v / v_{n}$ (viscosity changing in the $v_{\min } \leq v \leq v_{\max }$ range) on the value of loss coefficients $k_{i}$.

The method allows to evaluate the values and proportions of mechanical, volumetric and pressure losses in the motor (pump, driving system) and their dependence on the fluid viscosity $v$.

The knowledge of coefficients $\mathrm{k}_{\mathrm{i}}$ of the mechanical, volumetric and pressure losses allows to obtain, by applying a numerical method, a picture of the overall efficiency $\eta_{\mathrm{M}}=\mathrm{f}\left(\bar{\omega}_{\mathrm{M}}, \overline{\mathrm{M}}_{\mathrm{M}}\right)$ of the motor (pump and system) in the $\left(0 \leq \bar{\omega}_{\mathrm{M}}\left\langle\bar{\omega}_{\mathrm{M} \max }, 0 \leq \overline{\mathrm{M}}_{\mathrm{M}}\left\langle\overline{\mathrm{M}}_{\mathrm{M} \max }\right)\right.\right.$ motor operating field and for the selected ratio $v / v_{n}$ of fluid viscosity.

Simultaneously, the $\left(0 \leq \bar{\omega}_{M}\left\langle\bar{\omega}_{M \max }, 0 \leq \overline{\mathrm{M}}_{\mathrm{M}}\left\langle\overline{\mathrm{M}}_{\mathrm{M}_{\max }}\right)\right.\right.$ motor (pump and system) operating field is determined for a selected $v / v_{n}$ ratio of the working fluid viscosity to the reference viscosity.

It is assumed that the method is precise and simple in use. It reduces the necessary laboratory investigations of pumps and hydraulic motors. Il allows to seek energy saving displacement machine designs. It also allows to evaluate the drive energy efficiency and to seek energy saving structures of hydrostatic transmission systems.

\section{BIBLIOGRAPHY}

1. Paszota Z:: Graphical presentation of the power of energy losses and power developed in the elements of hydrostatic drive and control system. Part I - Rotational hydraulic motor speed series throttling control systems. Chapter in the monograph: „Research, design, production and operation of hydraulic systems" (in Polish), Adam Klich, Edward Palczak and Andrzej Meder editors. „Cylinder” Library. Komag Mining Mechanisation Centre, Gliwice 2008

2. Paszota Z:: Graphical presentation of the power of energy losses and power developed in the elements of hydrostatic drive and control system. Part II - Rotational hydraulic motor speed parallel throttling control and volumetric control systems. Chapter in the monograph: „Research, design, production and operation of hydraulic systems" (in Polish), Adam Klich, Edward Palczak and Andrzej Meder editors. „Cylinder” Library. Komag Mining Mechanisation Centre, Gliwice 2008

3. Paszota Z.: Direction of increase of power stream in the hydrostatic drive and control system. Graphical presentation of the power of energy losses and power developed in the elements of hydrostatic drive and control system. Part I - Rotational hydraulic motor speed series throttling control systems. (in Polish), Napędy i sterowanie, scientific monthly, No 10 (114), October 2008

4. Paszota Z.: Direction of increase of power stream in the hydrostatic drive and control system. Graphical presentation of the power of energy losses and power developed in the elements of hydrostatic drive and control system. Part II - Rotational hydraulic motor speed parallel throttling control and volumetric control systems. (in Polish), Napędy i sterowanie, scientific monthly, No 11 (115), November 2008

5. Paszota Z.: Graphical presentation of the power of energy losses and power developed in the elements of hydrostatic drive and control system. Part I - Rotational hydraulic motor speed series throttling control systems. Polish Maritime Research 03/2008

6. Paszota Z.: Graphical presentation of the power of energy losses and power developed in the elements of hydrostatic drive and control system. Part II - Rotational hydraulic motor speed parallel throttling control and volumetric control systems. Polish Maritime Research 04/2008

7. Paszota Z.: The operating field of a hydrostatic drive system. Chapter in the monograph: „Research, design, production and operation of hydraulic systems" (in Polish), Adam Klich, Antoni Kozieł and Edward Palczak editors. „Cylinder” Library. Komag Mining Mechanisation Centre, Gliwice 2009 
8. Paszota Z.: Parameters of the energy efficiency investigations of pumps and hydraulic motors. The operating field of a hydrostatic drive system. (in Polish), Napędy i sterowanie, scientific monthly, No 11 (127), November 2009

9. Paszota Z.: The operating field of a hydrostatic drive system parameters of the energy efficiency investigations of pumps and hydraulic motors. Polish Maritime Research 04 / 2009

10.Technical matter of the Hägglunds Company: Product Manual VIKING EN397-3a 1999

11. Technical matter of the Bosch Rexroth AG Company: RE 91 604/06.03 I AGVM

12.Technical matter of the Parker Hannifin Company: Catalogue HY30-8223/UK

13.Technical matter of the SAUER DANFOSS Company: Technical Information 520L0440·Rev AD·Dec 2009
14. Technical matter of the LABORATOIRE HYDRO LEDUC Company: Efficiency M series motors

\section{CONTACT WITH THE AUTHOR}

Prof. Zygmunt Paszota Faculty of Ocean Engineering and Ship Technology

Gdansk University of Technology

Narutowicza 11/12

80-233 Gdansk, POLAND

e-mail: zpaszota@pg.gda.pl 